\title{
ATLANT AND SLOVENE NATIONAL CONSCIOUSNESS IN THE SECOND HALF OF THE $19^{\text {th }}$ CENTURY
}

\section{ATLANT IN SLOVENSKA NACIONALNA ZAVEST V 2. POLOVICI 19. STOLETJA}

Mimi Urbanc, Jerneja Fridl, Drago Kladnik, Drago Perko

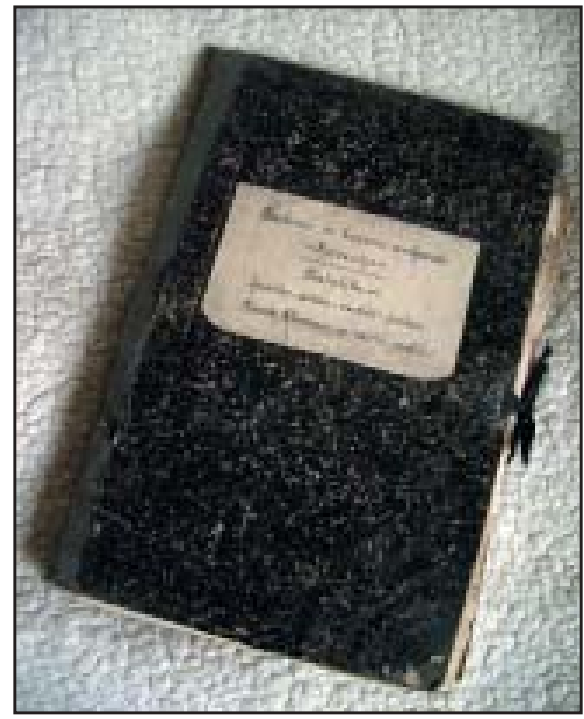

The folder where the original maps of Atlant were found (photograph: Milan Orožen Adamič).

Mapa, v kateri so bili najdeni originalni zemljevidi Atlanta (fotografija: Milan Orožen Adamič)

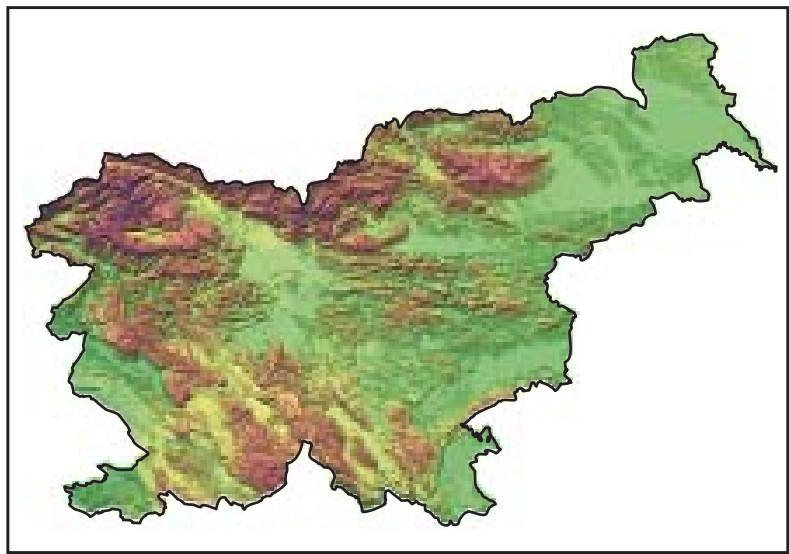




\title{
Atlant and Slovene national consciousness in the second half of the $19^{\text {th }}$ century
}

\author{
UDC: $912.44(497.4) " 19 "$
}

COBISS: 1.01

\begin{abstract}
The geographic literature made an important contribution to the development of national consciousness among Slovenes in the $19^{\text {th }}$ century, as well as to the reinforcement of Slovene identity after Slovenia's independence in 1991. A typical example of this kind of geographic publication is Atlant, the first atlas of the world in the Slovene language, which was published in installments from 1869 to 1877. Atlant followed the concept of a Unified Slovenia, and this idea boosted the confidence of Slovenes, the bulk of whom were incorporated into Austria-Hungary as they entered the stage of European politics as a nation for the first time. With the publication of Atlant, a number of geographical names were translated into Slovene or Slovenized for the first time. The geographic, linguistic, and political conditions in which Slovenes lived, as well as the relations at the time between Slovene, German, and Slavic languages, are reflected in the way foreign place names were adapted. The reprinting of Atlant in 2005 is also associated with a critical period in history, since it was published after the independence of Slovenia and its inclusion in the European Union, a time when the young state has been seeking its identity among all the world's nations.
\end{abstract}

KEY WORDS: historical geography, cartography, atlas, map, Slovenia, Austria-Hungary, geographical name, endonym, exonym, identity, nation building, national consciousness.

The article was submitted for publication on August 4, 2006.

\section{ADDRESSES:}

\section{Mimi Urbanc, M.Sc.}

Anton Melik Geographical Institute

Scientific Research Centre of the Slovenian

Academy of Sciences and Arts

Gosposka ulica 13, SI - 1000 Ljubljana,

Slovenia

E-mail:mimi@zrc-sazu.si

Jerneja Fridl, M. Sc.

Anton Melik Geographical Institute

Scientific Research Centre of the Slovenian

Academy of Sciences and Arts

Gosposka ulica 13, SI - 1000 Ljubljana,

Slovenia

E-mail: jerneja@zrc-sazu.si

\author{
Drago Kladnik, M.Sc. \\ Anton Melik Geographical Institute \\ Scientific Research Centre of the Slovenian \\ Academy of Sciences and Arts \\ Gosposka ulica 13, SI - 1000 Ljubljana, \\ Slovenia \\ E-mail: drago.kladnik@zrc-sazu.si \\ Drago Perko, Ph. D. \\ Anton Melik Geographical Institute \\ Scientific Research Centre of the Slovenian \\ Academy of Sciences and Arts \\ Gosposka ulica 13, SI - 1000 Ljubljana, \\ Slovenia \\ E-mail: drago@zrc-sazu.si
}

\section{Contents}

1 Introduction

2 Power, knowledge, and cartography as instruments of cultural identity and national consciousness

3 Historical background and space: the position of Slovenes within the multinational monarchy

Matica slovenska - transcending provincial borders, and its cultural activity

$\begin{array}{lll}10 & \text { Conclusion } & 267\end{array}$

11 References 268 


\section{Introduction}

"... When we look for traces of a unified Slovene people, the path is revealed mainly by linguistic footprints. It is the common linguistic and cultural consciousness that has given rise to the idea of a unified Slovene national body. The idea of Slovenes joining together is an explicitly cultural project, and has remained so for a long time even after it was formulated as the political program of United Slovenia ... (Kovačič-Peršin 2000, 27).

In this article we present the role and significance of the Slovene-language geography literature in awakening and cultivating Slovene national consciousness in the second half of the $19^{\text {th }}$ century. The process of shaping cultural identity through literature began among Slovenes at the time of the Reformation, and flourished in the wake of the bourgeois revolutions that occurred when constitutional and democratic principles began to be applied in the aristocratic absolutist state of the Habsburg Monarchy. An important part of this was the emphasis on the nationalist aspect, and the related right to use the mother tongue. This fostered the cultural development of small nations within multinational states, which in turn served as the foundation for the shaping of national consciousness. We place the development of national consciousness in the wider context of the Habsburg Monarchy, and explain it as a web of contacts, influences, views, and cooperation among German, Austrian, Czech and Slovene lands.

Specifically, we show the historical influence of the geography literature on the strengthening of national consciousness in the case of Atlant, the first atlas of the world in the Slovene language, printed in six sets of three sheets each between 1869 and 1877. Maps are an effective graphic means since they have a high communicative value and play a role in shaping one's approach to the world. They are also a testament to the way in which their makers, publishers and even a particular nation view their immediate as well as more distant surroundings and the world as a whole. The development of maps through history is thus indirectly connected with the rise of national states (Harley 2002). In this regard geographical names have a special role, since they extend the view of the environment and the world in which a society exists. Geographical names are also closely connected with linguistic reality, which applies to endonyms as well as exonyms. The communicative value of geographical names in the atlas under study is all the greater since its editor Matej Cigale was a linguist by profession. Due to a deficit of role models in the specialist literature, which at that time was sparse and incomplete, the geographical names in Atlant were the result of dedicated intellectual effort, and not the result of an uncritical adoption of names from similar publications. Cigale as a person was the prototype of the nationally conscious $19^{\text {th }}$ century intellectual. His biography also sheds light in no small measure on the society of the time.

Our intention in this article is to examine the first atlas of the world in the Slovene language as a source for the analysis of the time, space, and culture in which it appeared. We hope to highlight and evaluate

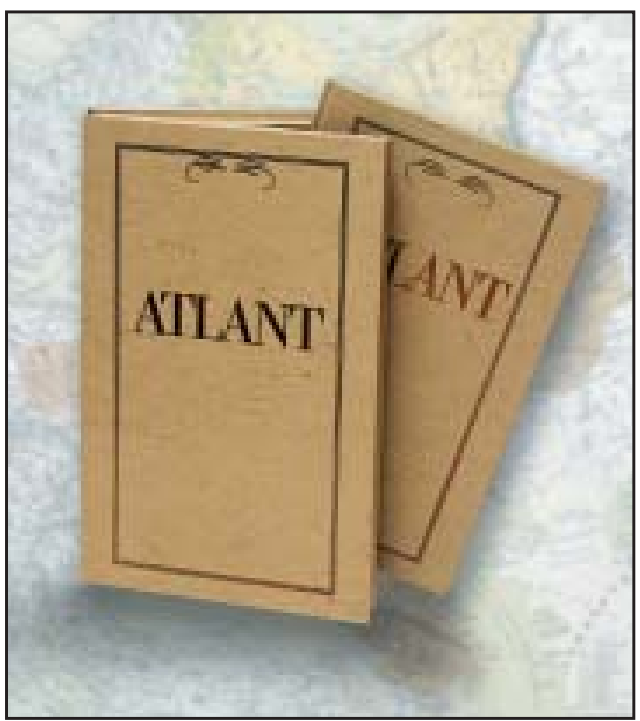

Figure 1: A facsimile of Atlant, the first atlas of the world in the Slovene language, which was published in a series of map sheets issued periodically from 1869 to 1877. 
its role and significance for the development of national consciousness among Slovenes. We have focused on the development of the consciousness of a national body as a nation, on the role of language in its formation and on the cultural aspect of this process. The study encompassed technical aspects of the project as well as content: it is important to look at what maps show as well as how they show it. The first relies especially on the spatial flows associated with Slovenes, and their chronology. The second aspect is more complicated and ambiguous, since it requires an accurate reading and understanding of the maps in Atlant, especially the geographical names. We were interested primarily in the cognitive level of Atlant, which indicates the status of Slovenes in a multinational state and the relationship of Slovene to other languages, not just German, but also Czech and other Slavic languages. Further, we would like to present Atlant as a medium through which the local or national was conveyed to the outside world, i. e. the international and global environment; the flows, of course, also occurred in the opposite direction. Atlant helped to erase the boundaries between the Slovene community and the wider world community, but at the same time it also helped to establish them anew. In this context it is necessary to understand the strategies by which the Matica slovenska, the organization which published Atlant, gained its readership, since these strategies helped expand the sense of awareness of belonging to a community.

\section{Power, knowledge, and cartography as instruments of cultural identity and national consciousness}

Maps have long been associated with the work of geographers, but especially as a tool for showing various kinds of findings. This is the source of the traditional view of maps as an abstraction of reality: that they reflect objective information about the surrounding environment (Soini 2001). When they are themselves the subject of study, it is usually the technical and technological aspects of map-making that are at the forefront. More rarely, they are used and understood as a »text«, or socially produced form of knowing. Seen in this light, maps are the result of a given stage of social and cultural development of a nation, and they reflect the view of the world held by their authors or makers (Pile and Thrift 1995; Dorling and Fairbairn 1997; Cosgrove 1999). With older maps, a new dimension relating to their nature as historical documents opens up, which reveals the political and cultural image of the periods in which they were created. In this way older maps acquire an important role in the examination of historical events; in our case their role in the rise of modern national states is especially significant, as Harley (2002) has already noted.

But Harley's observations are of only limited usefulness in our context. His reflections on the power of cartography can with certain modifications be applied to the Central European historical space as well. The Slovene reality was a little bit different. In Slovenia it was about the rise of a national movement, since the entire Central European space was from the standpoint of the formation of national states something of a historical latecomer. States began to come into being only after the collapse of the four transnational empires - Habsburg, German, Russian, and Turkish - in the First World War. Up until this time a number of nations had long been handcuffed to their »loving embrace«. Despite considerable differences, we can nevertheless draw some parallels and, with a few caveats, apply Harley's findings.

A map is the result of two groups of actors: map-makers and map-users. The first group is composed of the conceptual leaders, or the publisher and maker of the map. With respect to map-using, cultural, social, and political conditions and the desires and expectations of the public are at the forefront (Craig 2000). In map-making, the guiding principles of the publisher and map-maker is important. The map-maker usually just carries out the desires and demands of the person or organization that has commissioned the map. For precisely this reason maps have a high communicative value. »... There is no such thing as empty space on a map...", is the claim upon which Harley bases his conceptualization of maps (Harley 2001). His work is based on the conviction that a thorough investigation of the cartographic subconscious and its social foundations can reveal a hidden plan in maps. This is what gives maps their power, political as well as cultural, though it is at first glance invisible. Harley thus conceptualizes maps as objects of power and knowledge, and interprets their creation as a reflection of the political system.

Harley's view of the ideological power of maps can also be useful for our purposes, i. e. for the analysis of maps as an integral part of the development of national consciousness and the associated formation of national identity. First, the map should be understood as a kind of language, which, "written « for a spe- 
cific public, can be translated and explained. A further aspect is iconology, which reveals the deep, symbolic meaning as well as the supernatural, literary meaning. Last but not least, cartography can be understood as a form of knowledge. Harley built his understanding of maps on the assertion that the map-creator always manipulates users with his product. In his view, maps are evidence of the political and cultural aspirations of the map-creator (Harley 2001). In the case of Atlant, the most powerful tool of the map-author are the geographical names, since it is through them that he creates the language policy, and by so doing places Slovene on the same level as other European languages in countries with developed cartography.

The linguistic side of maps is shown on the one hand by the state or the developmental level of the language, and on the other by the view of their makers and the society of the time and space in which the maps arise. Geographical names are a favorite topic of geography as well as linguistics, and especially historical geography, since the names are real as well as metaphorical, actual as well as symbolic, and most of all they serve as a window on the current issue of power, culture, location and identity (Nash 1999). There are a range of definitions and views of them (Sauer 1966; Jett 1997; Claval 1998). For this article what is important is their role as a medium through which people develop their relationship to the environment they live in, and along with this their identity (Gams 1991; Yeoh 1996; Jett 1997, Berk 1998; Nash 1999; Urbanc and Gabrovec 2005). Often a psychological battle for the ownership of space is waged through toponyms (Cohen and Kliot 1992; Myers 1996; Harley 2001; Baskar 2004), whether this is colonial and physical appropriation, or occurs at a mental or spiritual level.

In the case of small nations located within multinational states, the claiming of space is conceptualized at the mental level, since it is about the (re)claiming of their own space and its formation into a national space. Anderson (1995) calls this process the formation of imagined communities, and points to printing as a basic landmark of this process. Here again we need to go back to the history of colonialism and draw parallels with national movements in Central Europe. Thus, for example, in colonized countries the local intelligentsia imagined its own national community when people began to read newspapers in their native languages (Anderson 1995). The majority of definitions of nationalism emphasize the political aspect (Gellner 1983; Anderson 1995), but this process of formation was different in those national communities which did not have their own ruling class, did not live in an independent state entity that coincided with the territory settled by this community, did not have a continuous tradition of intellectual creativity in their national language, or their national language was rooted out or in serious decline (Hroch 1985). In the examples listed above, there is a »revival « of an oppressed small nation with the help of cultural creativity, in which smallness is not meant in a numerical sense. According to Hroch, this process is relatively long in duration, since the transition to the political phase is not possible due to various circumstances. Even when the political demands are realized, these usually materialize first in the form of autonomy, not directly in independence (Hroch 1995). Here Hroch's analysis needs to be extended: it is true that in the initial period the national awakening was primarily cultural, but it was stimulated by certain political trends. It has an inherent political character since it was made possible only by a certain political situation. In the case of Slovenes it is true that it was possible to recognize the political demands in undertones (Vodopivec 1998).

Facts which impede the cultural emancipation of small nations can be divided into two types: internal and external. The first arise from the nation itself. In the case of Slovenes the most important of these was the incomplete social structure, since there was no domestic ruling class, or rather, it was poorly represented, and other classes and social groups were also atypically represented (Hroch 1985). External facts are those which originate from the state in which the nation lives. In the case of Slovenia, this was the Habsburg Monarchy. The set of factors which had a crucial influence on the life of small nations could be called the hegemony of the ruling class, which was accompanied by a certain degree of assimilation. In such circumstances the cultural identity was what constructed the national identity, which was most important for the development of a modern nation. Identity is a broad concept which reveals the collective images which establish the consciousness of a national community. If we consider the humanistic dimension of identity, it is a dialectical system combining two aspects: »we « and »they«. In the case of Slovenia this dichotomy encompasses not only duality on a horizontal axis, but also on the vertical axis, where there is a relationship between the concepts "from below « and »from above« (Paasi 1991 and 2003). Here it is important to note that this is essentially a relationship of power or mental boundaries. Thus the concept »they« is additionally weighted with the concept of »from above«.

In setting actual and mental boundaries, cartography and national consciousness are closely intertwined. Lilley (2000) asserts that map-making is a creative process which can be compared to writing a text, 
and that it mirrors the conceptualization of the environment and spatial representations of people. Thus cartography is a means of examining what comprises our external world and what comprises our internal world. In this light cartography is what sets the boundaries and at the same time helps to break them down or go around them, since it transmits the intellectual view and worldview of the map-creators to the wider community. It is a question of conveying an image which has been conceived of by the map-commissioner and the map-maker to the wider world, and in this way it is the achievement of a deeper communicative value. The printing of maps with Slovene names was intended primarily to erase the differences between "us" and »them «, since it put the Slovene national community in the company of other nations and brought it face to face with the cultural, national and political development of others. At the same time it clearly emphasized the presentation of "us " and protected the Slovene nation from merging with larger national communities.

\section{Historical background and space: the position of Slovenes within the multinational monarchy}

Slovenes since the early Middle Ages had not been politically joined in a national state. They began to be aware of their existence during the Protestant period, when the first Slovene book was produced, and this was intensified during the time of national re-birth in the second half of the $18^{\text {th }}$ century and time of the Illyrian provinces at the beginning of the $19^{\text {th }}$ century. Aspirations for a national independent existence of their own were expressed even more strongly during the revolutionary year 1848.

Prior to that the Slovene national movement was of an exclusively cultural nature. The ethnonym Slovene came into increasingly wider use, especially in the 1830s and 1840s, andreplaced the terms for members of the Slovene nation that had been in use up until then (Wenden, Kranjci denominating inhabitants of the Habsburg crownland Carniola). Although the name Slovenia to refer to the whole of the territory settled by Slovenes existed before 1848, it was a term which was unknown in geography and history and the existing administrative organization, and modern national consciousness came only gradually to the economic, cultural, and politically poorly integrated society (Ilustrirana zgodovina Slovencev 1999).

In 1848 Slovenes in Vienna formulated the program called United Slovenia. It contained demands for an administratively or politically united national territory which would emerge with the anticipated transformation of the Austrian empire into a bourgeois parliamentary monarchy and with the internal administrative reorganization of the state. The program filled Slovenes with the hope that a greater administrative entity of Slovenia, extending across all the territory populated by ethnic Slovenes, would come into being. The founding proclamation of the Slovenia society demanded »... that the politically dispersed nation of Slovenes in Carniola, Styria, the Littoral and Carinthia become as one nation in the single kingdom of a united Slovenia ... (Ilustrirana zgodovina Slovencev 1999, 227). The program of United Slovenia joined in the demands for language rights: for the equal status of Slovene with other languages (German, Italian) and for its use in schools, government offices, and courts. There was also a demand for a Slovene university.

The program was reinforced cartographically by the Map of Slovene land and provinces, which was published by the lawyer, geographer and politician Peter Kozler (1824-1879), by birth an ethnic German from Kočevje. He drew the Slovenian ethnic boundaries and provided justification for them in an accompanying pamphlet. The map was printed as early as 1853, but published only eight years later, in 1861, since it was affected by the sanctions of Bach's neo-absolutism, on the grounds that the map showed a non-existent political structure. The Map of Slovene land and provinces, which was reprinted a number of times, is still considered as one of the sacred objects of Sloveneness, due to its nationally charged nature.

However, the group, which proclaimed and backed the United Slovenia program was small in number and weak. They did not inspire any confidence at all in the peasantry, and received only a lukewarm reception among Slovene townspeople, since it seemed to many people, though well aware of their Slovene roots, too radical. Many were also bothered by the "Illyrian « orientation imposed by the leaders of the national movement, who advocated union with Croatia. Of course the United Slovenia program found even less sympathy among the German population in Slovene cities and towns.

Cigale's Atlant, which in some ways was the continuation of Kozler's map, anachronistically and in a perhaps politically motivated gesture named Slovenes' homeland at the time Austria: this map, which 


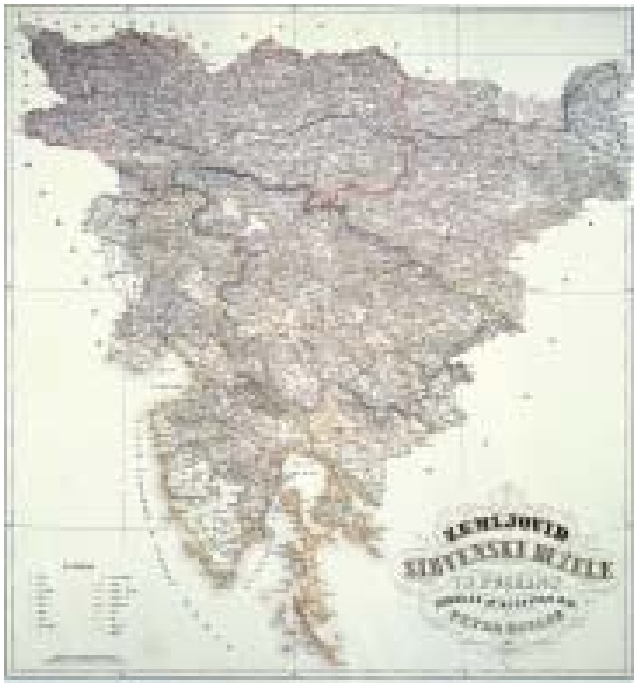

Figure 2: Kozler's Map of Slovene land and provinces, printed in 1853, is the first map to display the ethnic territory of Slovenes. Due to its politically controversial nature, it was not published until eight years later.

was published as the third map in the first bundle, was printed in 1869 , when the state had already borne the official name of Austria-Hungary for two years. It had just passed through two successive periods of serious internal political crises brought on by the severe defeats in the wars in 1859 and 1866, by means of which the Habsburg Court had intended to prevent the union of Italy and Germany. The first military catastrophe at the end of the 1850s caused a tectonic shift in the internal politics of the Habsburg monarchy. The bell had tolled for the absolutist regime, and there began a constitutional and state parliamentary and provincial parliamentary political life which was still far from democratic. This also marked the beginning of a new stage in the development of the Slovene national movement, which Bogo Grafenauer justifiably called »the affirmation of Slovene national integrity« (Čepič 1979, 964).

For the modern Slovene the view of the mosaic of historic provinces in which Slovenes lived back then is meaningful - in this way the fundamental demands of Slovene political life in the period of camps (1868-1871) for a united Slovenia and for Slovene as the official language become more understandable. The territory settled by Slovenes was divided among the provinces of Carniola in the middle, Carinthia in the north, Styria in the northeast, and the Littoral with Istria in the west. Despite the fact that the Venetian Slovenes and the Val Resia Slovenes remained outside the borders of the main Slovene state, this was still the most favorable border arrangement for the Slovene community with respect to Italy, and it lasted from 1866 up until the first world war. Carniola and the Littoral made up the bulk of the Slovene national territory, while Carinthia and Styria reached far beyond what was then populated by Slovenes into the heart of what is now the Republic of Austria. Slovenes in Prekmurje, the region on the left bank of the Mura River, belonged directly to the Hungarian part of the monarchy. Prekmurje was then, and is still today, Protestant, while the other Slovene lands were Catholic.

Due to German pressure the Slovene national border in the north gradually and steadily retreated south. In the middle of the $19^{\text {th }}$ century there remained just a small isolated island of Sloveneness south of Grossglockner; Slovene predominance in the upper Gailtal was lost, and the ethnic border began to approach the Drava. Slovenes predominated only in the countryside; in the cities they were mixed with Germans, and in the Littoral (with the partial exceptions of Trieste and Gorizia) with Italians. Due to their economic power, it was the cities which were the site of the most passionate battles for the dominance of one nationality over another; it is thus understandable that the institutions important for national development were based there.

The construction of the Vienna-Trieste railway line, which, beginning in 1857, connected the Slovene lands with the economically more developed heartland of the monarchy, represented a great economic achievement. The first major joint stock companies in Slovenia were created before the outbreak of the economic crisis in 1873. With some success they developed the coal, iron, paper, leather, brick-making, construction and beer-brewing industries, but the extent of domestic capital was relatively weak. In the 


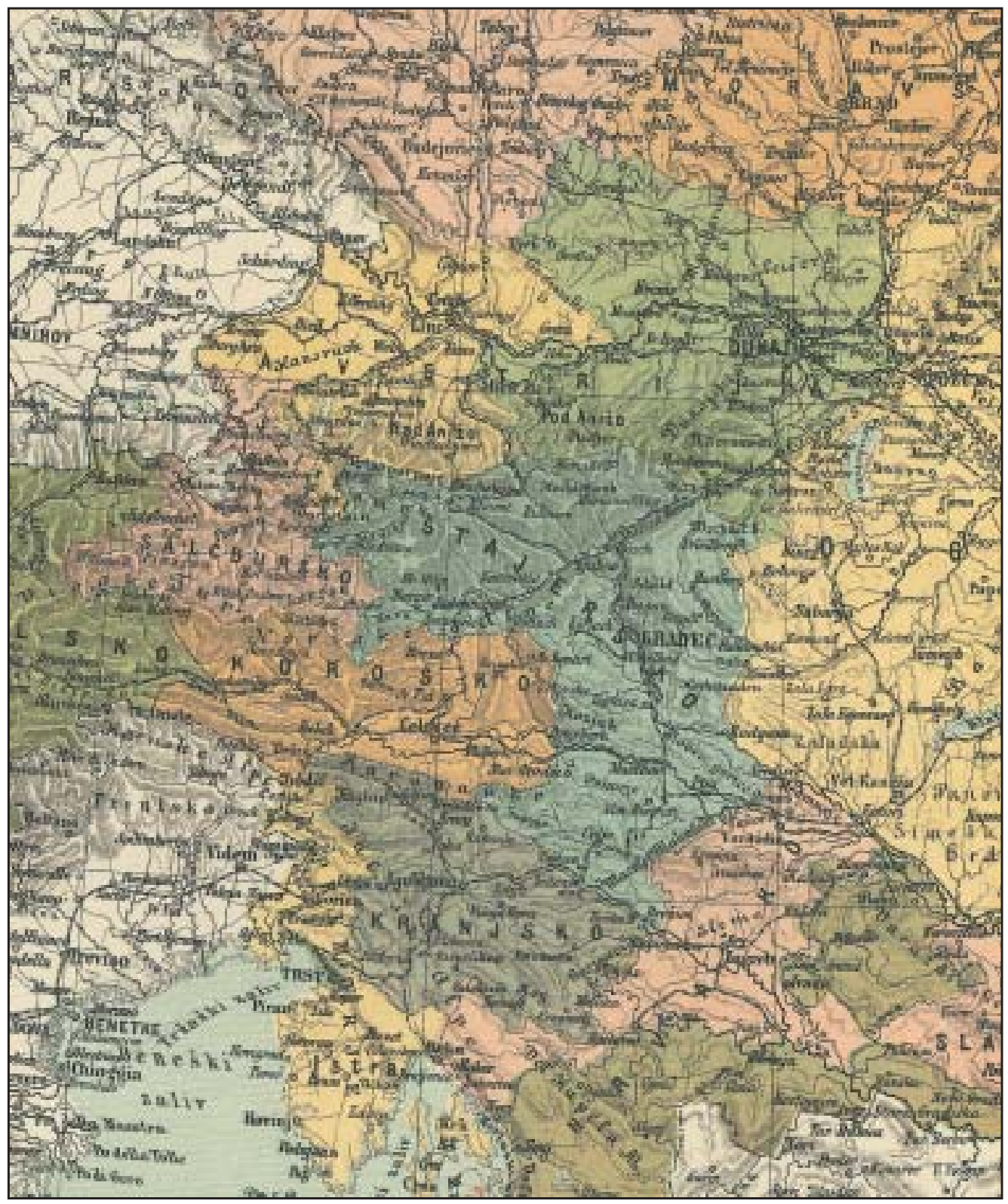

Figure 3: A section from the third map in the Atlant collection, which was published at the end of 1869 under the title »Austria« despite the fact that the joint state at the time was called Austria-Hungary.

middle of the $19^{\text {th }}$ century, the state bureaucracy, civil as well as military, experienced powerful growth. This opened the doors to the employment of large numbers of people. Even the Austro-Hungarian civil service, traditionally made up of aristocrats, greatly increased the share of employees from the middle class: from $0 \%$ in 1804 it rose to 55\% in 1878 (Anderson 1995). At the same time, the role of merchants and the industrial bourgeoisie increased. For Slovenes this meant that they could also become entrepreneurs and find employment in the civil service. This also had the effect of strengthening Sloveneness. However, Slovene society in the main remained an agrarian one. On the territory of what is now the Republic of 
Slovenia, $83 \%$ of the population gained their livelihood from farming in 1857, in 1880 this share was still $81 \%$, and even in 1910 it was as high as 67\%. Since farming was underdeveloped technologically, and holdings were small and fragmented, and since there was a chronic shortage of jobs to be found outside agriculture, there were waves of mass migration, especially to America. Emigration took up more than $50 \%$ of the natural growth of the population; as a result, the share of Slovenes in Austria-Hungary continued to fall everywhere (Ilustrirana zgodovina Slovencev 1999).

As early as 1861, when Franz Joseph I by means of the February Patent reorganized half the monarchy, there were Slovene literary salons established in Trieste, Maribor, and Celje; by 1869 these had multiplied to 57. They were meeting places for nationally conscious intellectuals, Slovene members of the urban and merchant upper classes, notables from the countryside, and the petty bourgeoisie; the peasantry was included only to a limited extent in only a few places, notably the Littoral. They hosted word games, recitations, songs, concert numbers, lectures and speeches, social gatherings, and dances. The center of these all-Slovene cultural and political activities gradually came to be located in Ljubljana, the capital city of the centrally located Duchy of Carniola, the Habsburg inherited property settled by Slovenes. At the end of the 1860s, Ljubljana's literary salon had about 300 members, and was the central organization of which other reading rooms were affiliates. The seat of the gymnastics society »Južni sokol « (Southern Falcon), founded in 1863 after the Czech model, was also located in Ljubljana. A year later the Matica slovenska was founded, the first domestic society for the publication of scientific, popular and other books in the Slovene language, and two years after that the Drama Society, which was the forerunner of the Slovene National Theater (Šumrada 2005).

Ljubljana during this period was undeniably also the center for the conservative old-school Slovene politics led by Janez Bleiweis (1808-1881) and promoted in his newspapers: Slovene Economic, Crafts and National News (1843-1902) and the German Triglav (1865-1870). The Slovene political option of the newer school, led by the composer and poet Miroslav Vilhar (1818-1871) and the writer Fran Levstik (1831-1887), which clearly and uncompromisingly backed United Slovenia and the public use of Slovene, was unable to attain prominence since its newspaper Naprej (»Forward «) was suppressed in 1863 after less than a year of activity (Šumrada 2005).

The Habsburg military defeat by Prussia in 1866 had a favorable influence on the democratization of the political life of Slovenes and accelerated its political and cultural development. The Viennese ruling circles resolved the military fiasco with a political settlement or treaty with the Hungarian elites and the reorganization of the state into a dualistic monarchy in 1867, carried out at the expense of the Slavic nations. The Austro-Hungarian Monarchy ceased to be a great European power and began increasingly to rely on its German neighbor, becoming ever more dependent.

\section{Matica slovenska - transcending provincial borders, and its cultural activity}

The English historian A. J. P. Taylor wrote that some nations, or at least their embryonic beginnings in the Habsburg Monarchy, were in fact created by people of the pen (Grdina 1999). Slovenes built their cultural struggle based on the views of the German philosopher Herder, who regarded language as the foundation of every nation, and hence placed culture on the altar of their formation (Seton-Watson 1980). Herder's work was also inspired by the idea of a Slavic association, called pan-Slavism, whose leading figures encouraged substantiation of the differences between Slavic nations and Germans, by means of which they drew distinctions between the two groups. In his famous work Ideen zur Geschicte der Menschheit from 1784, Herder ascribed to the Slavs - in contrast to the Germans - leanings towards democracy, peace, music, and national poetry. Important also was the fact that the movement was not directed against the Monarchy, though it did demand its transformation (Čepič 1979; Hroch 1985; Melik 1998; Grdina 1999).

The basic demand was that all the territory inhabited by Slovenes should be united in one whole. It was clear that the fragmentation into different provinces needed to be overcome, and Slovenes joined. This struggle for the consolidation of Slovene territory began first in the spiritual sphere, especially through cultural activity. The leading role in this cultural battle was taken by the Matica slovenska, an all-Slovene publishing, scientific and cultural society. The word 'matica' as the name of a national organization responsible 
for publishing books became widespread among the western and southern Slavs during the first half of the $19^{\text {th }}$ century. It first appeared in Slovene territory in 1845, in the weekly Farming and Handicraft News in an article about the efforts to establish such a society. The main purpose of the Matica was the dissemination of literature in the Slovene language, thereby counteracting the influence of the German language and Germanization, which was more or less a byproduct of the aspirations for unification in a state and the organization of an efficient state administration. In the first decades of its operation the Matica sloven$s k a$, as a central cultural institution, replaced the university and the academy of arts and sciences, earning it the title of » the mother of our scientific literature " (Melik 1997). Its universal national character meant that it led the second phase of the national movement, which according to Hroch followed the period of »interest among the learned classes, « the period of so-called »patriotic agitation « (Hroch 1985). During this period the process of formation of national consciousness began, and the ideas of the original enthusiastic visionaries spread to the masses. The activities of the Matica slovenska were presented not only in its publications and Yearbook, but also in the Slovene popular weekly Economic, Crafts and National News, edited by »father of the nation « Janez Bleiweis. As the name itself already indicates, the newspaper was intended first of all for the »ordinary person «, in hopes of elevating him to a higher economic and cultural level, but also for the educated classes. The use of the language of the people made Slovene literary and scientific works more accessible to the public: Bleiweis saw language and culture, grounded in peasant traditions and Slavic harmony, as the most effective means of national liberation (Slovenski narod 1873).

At the very outset the Matica slovenska undertook to make up for the lack of Slovene folklore and local history reading material by publishing historical and geographical descriptions of the Slovene lands, which educated Slovene patriots and members of the board began to prepare at this time. This was in keeping with the idea that the power and stature of a nation springs from books in the mother tongue, which the nation can be justly proud of. The need for geographical literature arose from the conviction that a stronger national consciousness required a good knowledge not only of one's own country but also of foreign lands both near and far. It is important to note that the Matica was a supraprovincial organization which strove in its work to transcend provincial borders and satisfy the needs of all its members regardless of which province of Austria they lived in.

The Matica began its publishing activity with geographical works, or more precisely, with cartography. In addition to the Slovene Calendar for 1865, its members also received Kozler's Map of Slovene land and provinces, which was the author's gift to the Matica. Besides its undeniable scientific value, since it was created based on state statistics and field observations, its moral value was inestimable, since it showed the united territory of the Slovene nation in a new light. It is thus understandable that it served for the next hundred years as the underpinning for Slovene national demands (Prunk 2000). With the publication of a map that clearly expressed the aspirations for a United Slovenia, the Matica early on indicated its primary role.

The books which followed reflected similar ideas. Their main purpose was to present the provinces within the Habsburg Monarchy in which there were concentrations of Slovenes, and in this way show that the provinces belonged to Slovenes. They strove to clearly illustrate the territory settled by Slovenes as an independent entity within the Monarchy (Granda 2001). The first two geographical publications were The Duchy of Carinthia in geographical, statistical, and historical overview, and The Duchy of Carniola in geographical, statistical, and historical overview. The author of both was Josef Erben, a professor at the University of Prague, and the translator was Matej Cigale. This was followed by a description of Styria, after which the idea of a detailed survey of all the provinces died away. It was revived again in 1892, but the collection Slovene land was not realized in its entirety. In contrast to the first attempt, the authors in the second were predominantly Slovene. Textbooks in Slovene were also initially only translations of foreign works. Matej Cigale translated and adapted Schubert's geography textbook with the title First lessons in geography for the first class of lower gymnasia and schools, but the work was never published. Of special value in the works in which Cigale collaborated were the Slovene geographical names and specialized expressions, since all the educated people of that time who dealt with maps or local history felt the lack of Slovene geographical terminology (Bohinec 1925). The first secondary school textbooks for geography authored by Slovenes came out in the 1860 s and 1870s. They were written by the nationally conscious Slovene Janez Jesenko (1838-1908), a geographer and historian educated at the University of Vienna, for publication under the auspices of the Matica slovenska. 


\section{Matej Cigale, Slovene intellectual}

Matej Cigale (1819-1889) was the prototype of the nationally conscious intellectual (Vodopivec 1998). He was born into a peasant family but early on showed great aptitude for learning, which took him to schools in Idrija, Gorizia, Ljubljana, Graz, and finally Vienna. At the lyceum in Gorizia he learned classical, Romance and Germanic languages. In the course of his studies of theology and later, law, he expanded his knowledge to include the Slavic languages, in particular Croatian, Serbian, Russian and Czech. In the revolutionary year 1848 he passed the exam to qualify as a judge in Klagenfurt, but due to a lack of funds was unable to pursue his occupation of choice; judges' clerkships were not paid, and state financial support was temporarily halted due to the revolutionary events.

At the invitation of the printer Blaznik, Cigale took over the editorship of his new newspaper, called Slovenia, in Ljubljana, and became a secretary of the Slovene Society, whose fundamental purpose was to cultivate the mother tongue and literature. But at the end of 1849 fate took him once again to Vienna, where he was appointed the Slovene editor of the state legal code on the state commission for judicial-political terminology for Slavic languages. This appointment led him away from working as a judge once and for all: to the end of his life he was involved with Slovene legal terminology and translations of all laws, decrees, orders, and official public proclamations. He conscientiously »... sorted, ironed and tidied up the language for the use of lawyers ... « for a full 38 years, and as a reward for his dedicated service was appointed as a government councilor (Majaron 1887 and 1889; Navratil 1894).

The fundamental guiding principles which drove his life and work were Slavic mutuality and the development of the Slovene language: »... to purify and develop Slovene, but not with the intention of increasing the differences among Slavs today, when a coming together is desired... (Majaron 1887, 252). His work in developing geographical sciences was also motivated by patriotism and the good of the Slovene nation, in which he regarded language as the foundation for national consciousness. Cigale belongs in the category of nationally conscious Slovenes whose status and position was not achieved in the field of economics or business, but who rose to their positions in public administration, free-lance occupations and other intellectual services by virtue of their education (Vodopivec 1998).

\section{Atlant: the first atlas of the world in the Slovene language}

The publication of Atlant, the first atlas of the world in the Slovene language, was a step forward. Earlier geographic publications were concerned primarily with the territory settled by Slovenes, and they wanted to reinforce awareness of the "Sloveneness « of the lands inhabited by Slovenes. The Matica slovenska, however, saw Atlant as a means of placing Slovenes and the Slovene language in a larger context, on the world map, to place the Slovene language side by side with languages of larger nations and tell Slovenes that they were an equal part of the planet. Today we might call this a transition from the local to the global.

The first atlas of the world in the Slovene language was published three centuries after the publication of the first Slovene printed book, Primož Trubar's The Catechism, in 1550, and the publication of the first atlas of the world anywhere, Abraham Ortelius's Theater of the World (Latin Theatrum orbis terrarum) in 1570.

Atlant was published in sheets. Three sheets each came out in the years 1869, 1871, 1872, 1874, 1875 in 1877, for a total of 18 maps. The majority were $40-42 \mathrm{~cm}$ long and $30-32 \mathrm{~cm}$ wide. Their titles were as follows: Face of the whole Earth in hemispheres; Europe, Austria, the German Empire; Switzerland, Italy, Spain and Portugal; France, the Netherlands and Belgium, Great Britain and Ireland; Scandinavia, Russia, Turkey and other eastern lands; Asia, Africa, North America, South America, and Australia. The geographical names were prepared by lawyer Matej Cigale (1819-1889). It is notable that for the Atlantic Ocean, Indian Ocean, and Pacific Ocean he used the names Atlantsko morje (Atlantic Sea), Veliko morje (Great Sea) and Indijsko morje (Indian Sea), and for Antarctica Južno-tečajna celina (the South Pole continent). For Villach he wrote Belak, for Tarvisio Terbiž, for the Croatian city of Osijek Osek, for the Serbian city of Belgrade Belgrad, for Munich Mnihov, for Basel Bazileja, Bucharest Bukreš, Istanbul Carjigrad, for Denmark, Norway and Sweden Danija, Norvegija and Švedija, Scotland Škocija, and for the Mediterranean Sea Srednje morje. Although some geographical names today sound unusual or even comic, Matej Cigale completed an extraordinary opus, since for the first time numerous foreign names were translated into the Slovene language through translation or Slovenized. 
Despite its huge significance, Atlant was very nearly consigned to oblivion, as indicated by, among other things, the fact that a detailed survey of Austrian cartography shows that not even the comprehensive publication Atlantes Austriaci mentions Atlant (Dörflinger and Hühnel 1995).

After Slovenia's independence in 1991, the new state tried to strengthen Slovene identity, similarly to Atlant in the $19^{\text {th }}$ century, and gave special attention to fundamental geographic works. A number of extensive works about Slovenes, Slovenia and Slovene regions were published (Orožen Adamič et al. 1995; Perko and Orožen Adamič 1998; Fridl et al. 1998; Fridl et al. 2001), and in 2005 the Anton Melik Geographical Institute of the Scientific Research Center of the Slovene Academy of Arts and Sciences reprinted Atlant (Fridl et al. 2005). The publication is composed of 18 folded color map facsimiles with accompanying notes on 96 pages. The maps and the book are packaged in a cardboard case.

\section{Cartography as a form of knowledge}

Maps not only show the natural state of space, they also express a range of historical, social and political events in a given period. This is especially pronounced when features which are usually invisible to the human eye are displayed alongside visible forms. The cartographic definition of maps as a reflection of the world at a given time has for many years been inadequate and even inappropriate, since it covers only the technical procedures and cartographic knowledge mirrored in the »increasingly accurate portrayal« of reality (Pickles 1992, 194). Deeper sociological analysis shows maps in a new light, treating them not merely as a tool for orientation and for locating certain places and occurrences in a given time period, but also recognizing their much broader communicative value. Seen from the theory of intertextuality, maps are "graphic texts«; like landscapes, musical compositions and architectural structures, maps are categorized as non-literary texts. The metaphor of the map as a language is opposed by some cartographers, since literally they have no grammar and lack the temporal sequence of a syntax (Harley 1992), but "what constitutes a text is not the presence of linguistic elements but the act of construction « strukturiranja (McKenzie 1986, 35). Seen from this standpoint, maps fit the definition of a text, since it is a known fact that cartographic symbols as a code of communication were developed even before codes based on letters.

The development of cartography from the time of Eratosthenes on was directed by the ruling classes, who had power and authority, and knew that maps, due to their visual power, were an extremely useful medium for the cultural, ideological, and national appropriation of reality (Šaver 2005). Proof of this can be seen, for example, in the efforts of various rulers to use as the prime meridian one that ran through their territory or state. The decision of the French king Louis XIII in 1634 to use Ferro, the westernmost of the Canary Islands, as the prime meridian, influenced the choice of reference meridians for the maps of Atlant. The same point of reference was later taken by Austria-Hungary (Fridl 2005). The issue of where the prime meridian should be located became especially controversial at the beginning of the $19^{\text {th }}$ century, when the cartographic superpowers designated as prime meridian whichever one ran through their astronomical observatory. Thus the French chose the one through Paris, the Russians the one that passed through Pulkovo, near St. Petersburg, the Italians, Monte Mario in the vicinity of Rome, and the English, Greenwich, with its observatory, in the vicinity of London (Slukan Altić 2003). This lack of consensus could be seen in Atlant: some maps featured two prime meridians, Ferro and Paris. Greenwich was officially designated the international prime meridian at the International Meridian Conference in Washington, D. C., in 1884, which indicates the pre-eminence of the British Empire at the time.

Maps of the world, continents, and provinces began to take on more modern form in the $16^{\text {th }}$ century, assisted most of all by the aspirations of European rulers to discover and claim new lands as well as by the arrival of technologies from the Far East, especially China, in Europe. All this made it possible for the empty spaces on world maps, which from the $14^{\text {th }}$ century to the beginning of the $19^{\text {th }}$ century were covered with images of mythical figures, to gradually disappear. More accurate calculations of the latitudes and longitudes of various places on the Earth were made possible by the modernization of Ptolemy's cartographic projections, which along with the reprinting of his works had prevailed up until the first half of the $16^{\text {th }}$ century. But much time was to pass before the first general geographical map of Europe similar to today's was made, using the more accurate topographical maps of individual provinces. This occurred at the beginning of the $19^{\text {th }}$ century, during a period when the first aspirations towards placing the Slovene nation on the political map of Europe appeared (Fridl 1995). 
In the preparation of their first atlas of the world, Slovenes undoubtedly relied heavily on the works of German cartographers, as evidenced by among other things the appearance of the maps of Atlant. The hachures method invented in the $18^{\text {th }}$ century by Prussian military cartographers was used in order to show three-dimensional relief in a two-dimensional plane. In 1799 the method - then called slope hachuring - was further improved by the Saxon cartographer Johann Georg Lehmann, who accurately determined the ratios between the gradient of the land and the density of lines (Perko 2001). Its shortcomings could be seen especially in the display of mountain regions with steep relief. Two illustrative examples can be seen in the Alps as shown on a map of the German Empire and a map of Switzerland. Due to the larger scale, the lines on the map of Switzerland take up almost half the area, such that the other topographic elements in it literally disappear.

It is possible to assert with confidence that a variety of cartographic plans were used for the individual sheets of Atlant. This is demonstrated, for instance, by the fact that on some maps, for example the sheets of Europe, Asia, and Australia, rivers are shown as excessively meandering. River bends are distributed evenly along the length of the river course, such that it is obvious at a glance that the river's actual course is not being shown. This method of displaying river networks was typical for maps which came out about 200 years before Atlant. These shortcomings were corrected on later map sheets.

Atlant, with its clearly delineated political and administrative borders, is an important historical document. Slovene territory is still not perceptible among the major empires, smaller states and numerous colonies. Slovene toponyms, which indirectly show the regional characteristics and the ethnicity of Slovenes to a given territory, are sufficiently important for the understanding of space in a given historical period as to require a chapter of their own.

The path to the affirmation of the Slovene language in the broader context of the European cultural space was not easy. Some already established cartography publishers were not willing to publish an atlas in the Slovene language, using the excuse that it would be too expensive or that they already had too much work. The Matica slovenska finally concluded a contract with Friedrich Köke, owner of a geographical institution in Vienna. Atlant was printed using what was for those times a revolutionary printing technique - lithography, which had begun to be used in cartography only a few decades earlier. From the standpoint of technical procedures as well as their intertextual role, Atlant's maps were on a par with the world atlases of nations which were linguistically much more established in the $19^{\text {th }}$ century.

In referring to Atlant, we must therefore not only be aware that its system of cartographic symbols operates at the primary communicative level, i. e. the level of cartographic signs, but also that it should be understood metaphorically from the standpoint of the theory of intertextuality. This means that its secondary messages must also be recognized as they were shaped by the historical and social position of European nations in the second half of the $19^{\text {th }}$ century.

\section{Comprehending the world through geographical names}

Geographical names provide information about the natural geography, culture, history and people of a given region. A place's features are named not only on the basis of their natural properties, but also according to important personalities, historical events, literary works, religious tendencies and even humorous circumstances. A given name in different lands can for example along with its local variants explain the dissemination of a given cultural or historical factor, such as military conquest or colonization (Kadmon 2000). The meaning of geographical names for human society has been instructively defined by Vallières (1992, 46): »... Toponymy, whether we admit it or not, is part of the basic knowledge of every person on our planet...«, since without geographical names we would be deprived of one of the most important spatial frameworks for the local as well as wider environments in which we live on Earth. Or, as Ó Maolfabhail $(1992,11)$ adds: »... Our maps remain bereft of connection to humans until they are enriched with geographical names...".

Foreign geographical names in Slovene first began to appear in textbooks in the first half of the $19^{\text {th }}$ century. The first of them were presented systematically and in greater number by Janez Jesenko, whose textbook (Jesenko 1865) first cited Slovene names of continents and major world oceans and subsequently listed names on individual continents for major peninsulas, capes, and countries, or the better known regions, as well as the names for seas bordering the world oceans, and their major gulfs. He also labeled the major 
islands and most famous channels. Later he labeled major lakes and rivers, mountain ranges, their better known summits, and major lowlands on the continents. The names of major European cities and the largest cities on other continents were listed in table form.

Jesenko's collection of several hundred geographical names definitely served as an important model for Cigale's later work in the preparation of Atlant, even though he roundly criticized some of Jesenko's choices, in polemical articles published in newspapers. No doubt some of this was due also to rivalry. Cigale was especially critical of Jesenko's general expressions, whereas the geographical names did not draw major objections (Kladnik 2005).

There are 28,075 names and general concepts recorded in total on all the maps of Atlant. Of these, 5907, or 21\%, have been Slovenized. There are 22,233 different names, and 5842 are listed two or more times. 4651 different geographical names have been Slovenized (Kladnik 2005). All the major important geographical names have been Slovenized, and we thus can justifiably recognize Cigale, influenced in part by Jesenko, as their source.

Despite its exceptional significance in the development of the Slovene language, Atlant later failed to generate the response it deserved. Even more, Bohinec (1925) wrote in the first issue of The Geographical Bulletin that Cigale saw only a philosophical problem in Atlant, in which the accurate presentation of place names and additional terminology was its only good side, which for geography » does not signify any progress, " (Bohinec 1925, 13) since the geophysical side was completely neglected as was a methodical survey. How mistaken he was! Despite a few shortcomings, all 18 map sheets rank alongside the cartographic achievements of Kocen and others from the second half of the $19^{\text {th }}$ century, and as far as content is concerned Atlant is an invaluable resource for the study and understanding of Slovene geographical nomenclature. The Slovene language has thus been enriched with a multitude of Slovenized geographical names for nearly 150 years.

Cigale had an extraordinary feeling for the balanced Slovenization of names from all parts of the world. Although we wouldn't say that any given language inspired him, it is clear that he relied on the semantic type of geographical names and on the meaning of a given name originating from the size category of a certain feature. Larger and historically more important regions, mountain ranges, rivers, and other features were partly translated and partly transcribed, so as to adapt the nomenclature to the Slovene alphabet, and partly adapted to Slovene pronunciation by means of phonetic spelling, in which Slovene endings were added as necessary. For example, he translated the names of British Columbia (Britanska Kolumbija), the Rocky Mountains (Skalno gorovje), the Pacific Ocean or Mare Pacifico (Tiho morje), Lake Superior (Gornje jezero) and James Bay (Jakopov zaliv), as well as some names which are now rare (for example, Modro gorovje for the Australian Blue Mountains), appear again (for example, Nebeško gorovje for Tian Shan, which used to be Slovenized according to the Russian model as Tjanšan), or are no longer Slovenized (for example, Kraljičina dežela for Queensland or Novi Jork for New York). Examples of names which are transcribed are Beludžistan (Balūchistān), Jenisej (Enisej), Šan-tung (Shandong) and Okinava (Okinawa Jima), and examples of names adapted to Slovene pronunciation are Estremadura (Extremadura), Kalifornija (California), Sumatra (Sumatera), Tasmanija (Tasmania) in Loara (Loire).

Similar to modern maps, the proportion of Slovenized names is greater on general maps of the world and continents, and smaller in displays of individual European countries, with the exception of »homeland « Austria. Thus on the maps of » The Face of the Entire Earth in Hemispheres « 56.5\% of the names were Slovenized, on maps of North American, 45.3\%, maps of Europe, 44.7\%, and maps of Asia, 43.3\%. The maps of Australia and Austria have similar proportions of Slovenized names, with $35.5 \%$ and $35.3 \%$, respectively, while the maps of Africa with $22.4 \%$ and South America with $19.8 \%$ were roughly on a par with the German Empire (26.6\%), Turkey (22.7\%), and Russia (also 22.7\%), i. e. nearby lands in which Slavic roots are (or were) strong, an important factor in the Slovenization of names (Kladnik 2005).

The proportion of Slovenized names varied greatly depending on their semantic type. Names of peoples, continents, and historical regions are Slovenized in their entirety. The majority of names are Slovenized in the names of countries (81.9\%), marine water bodies (79.2\%), coastal landforms $(61.3 \%)$ and administrative units $(55.8 \%)$. The extent of Slovenization of names of settlements is considerably less: only $8.7 \%$.

Written forms of names, with the exception of those rewritten from Cyrillic, which in many instances led to Slovenization, are relatively divergent from modern transliteration norms for individual languages, but this indicates Cigale's considerable expertise in the characteristics of certain other languages, their stress patterns, and the way they are written in the Latin alphabet. This is confirmed by guidelines for the pronunciation of clusters of letters in individual languages written in the margins of some maps. 
The Slovenization of names followed the spirit of pan-Slavism, which at that time was very much alive; thus, wherever Slavic names were in use, these were written in Atlant. Thus we find, for example, in the territory of what is now Romania, names like Kraljevo (Craiova), Belgrad (Alba Iulia) in Oraštje (Oraștie). Perhaps even better examples can be found in the territory of what is now Germany. Wherever Lusatian Sorbian names occurred, these were written in Atlant. Thus, for example, in Mecklenburg and Brandenburg, we find the following names of settlements: Roztoki (Rostock), Ribnica (Ribnitz-Damgarten), Plava (Plau), Branibor (Brandenburg) and Devin (Magdeburg). The bulk of Polish and Russian names were also Slovenized, as well as a number of names on the Balkan Peninsula, for example Baker (Bakar), Kladenj (Kladanj), Čaček (Čačak), Kragujevec (Kragujevac) and Belgrad (Beograd).

In Slovenizing geographical names, Cigale relied on the nomenclature used in Czech atlases, which first came into existence in the middle of the $19^{\text {th }}$ century, a good two decades before Atlant (Zeměpisný atlas podle nejnowějších pramenůw a pomůcek 1842; Merklas 1846). This can be seen in the names of major cities in the south of what is now Germany, which are obviously written according to the Czech model, but following the rules for Slovenizing the Czech language: Mnihov, following the Czech Mnichov for the German München (English: Munich), Rezno (Czech: Rezno, for Regensburg), Norimberg (Czech: Norimberk, for Nürnberg/Nuremberg) and the perhapsR most interesting example of all, Moguč (Czech: Mohuč for Mainz, derived from the Latin name Moguntium). Similarly, the Italian Adriatic port city of Ancona was preferentially written in the now completely unknown variant of Jakin (the Czech name). Interestingly, Cigale did not use the Czech model for the Italian port city of Genova (English: Genoa).

Otherwise, Atlant uses some German and English names for distant lands which Cigale either did not want or did not know how to Slovenize. Typical examples are Peterhof (Petrov Dvorec, in Russia), the cities of Tiflis (Tbilisi, in Georgia) and Oporto (Porto, in Portugal), and the islands Grenadinen (the Grenadines, in the Lesser Antilles). A number of geographical names indicate the political, national, and linguistic realities of the second half of the $19^{\text {th }}$ century, which considerably differed from the present-day state of affairs. Thus for present-day Kaliningrad (formerly the East Prussian Königsberg) the Slavic name of Kraljevec was used, for the Finnish cities of Helsinki and Turku, the Swedish names of Helsingfors and Åbo were used, for the Latvian city of Jëkabpils the German name of Jakobstadt was used, for the Romanian cities of Constanţa and Beiuş, the Turkish name Köstendže and the Hungarian name Belenyes were used, for the Croatian city of Nerežišća on the island of Brač the Italian name Neresi was used, for the city of Trento in the Southern Tyrol the German name Trident was used, for the French city of Strasbourg the German name Strassburg was used, and for the Belgian city of Liège the Germane name Lüttich was used (Kladnik 2005).

The gap between well-known lands, with already elaborated nomenclature, and those which European explorers were only just beginning to »discover« is perceptible. There are vast empty spaces in the heart of Africa on the maps of that continent, with some "exotic « names listed in the margins, many of which have now vanished without a trace. A similar situation occurs in parts of Oceania.

Although some of the geographical names of the time sound unusual and even comical today, Cigale accomplished an extraordinary feat by translating and Slovenizing numerous foreign names and presenting them systematically in the Slovene language for the first time. It is impossible to overlook his critical approach, since Atlant provided some extremely good solutions which were later distorted due to the influence of Serbo-Croatian and Russification. For example, Cigale used the general Slovene expression »dežela « for "land « in the names of some regions in the Arctic and Antarctica as well as in Australia (e. g. »Wilkezova dežela « for Wilkes Land in Antarctica, »Washingtonova dežela« for Washington's Land in Greenland, and Van Dieman's Land, or Tasmania, in Australia). Until recently these names, based on the Serbo-Croatian model, were written with »zemlja« in place of »dežela.«

\section{Atlant as a mirror of representations of oneself and others}

In the second half of the $19^{\text {th }}$ century, the Slovene language slowly and with difficulty advanced from use as the everyday language of uneducated people to the language of government offices, courts, and school classrooms, and along with this, to a language which enabled scientific creativity. It was during this period, particularly after the renewal of constitutionality, that the language made great strides of progress. Constitutional life strengthened of its own accord and brought about the development of a rich literary language with great expressive powers (Čepič 1979). Scientific terminology was expanded, and Matej Cigale played a prominent 
role in the endeavor by establishing the foundations of Slovene as a language of science. This was very important for Slovenes for their positive self-image and the image they projected to the outside world. It was during this time that a language which had long been considered as a language of peasants began to enable scientific and cultural creativity of the highest order.

Atlant as a literary and scientific work as well as a historical document is a reflection of the time and space in which it arose. Just the course of the organizational activities itself, in the light of spatial relations, shows the position of Slovenes in search of their own space within a multinational monarchy and the relationship between Slovenes and the other nations there. In searching for the appropriate cartographic plans and institutions willing to take on such a challenging project the organizers turned first to two German publishing houses and one Czech one. The choice of German publishing houses shows that just a little over a year after the collapse of the German Alliance and the expulsion of Austria from it, which Slovenes received with great joy, the leading figures at the Matica had already transcended the conflicts between Austria and Germany (Melik 1993). Due to an incompatibility of interests regarding the printing of Atlant on the part of publishing houses approached, in the end the job was done in Vienna, in the capital where Cigale worked like many other Slovenes from the educated classes. Thus Atlant was the fruit of Austrian technology and cartographical science and Slovene linguistic expertise, given that its translator and editor was a Slovene.

The significance of Atlant and other scientific literature was that its existence refuted the arguments of government representatives who claimed that a lack of suitable terminology and an insufficient level of development of the language represented insurmountable obstacles to its use as an official language. This was the counterargument of German and Italian politicians who defended their position as colonial powers (Moritsch 1997). Atlant was proof that even a suppressed nation was capable of creating important cultural works and that Slovene as a language made this possible. It proved to Slovenes as well as to others that Slovene was a living language which was actively developing. It highlighted Slovenes as a national community well along the road to shaping its own identity. The work of the Matica slovenska demonstrated that Slovenes did not intend achieve national emancipation solely through political struggle, but spontaneously, through the strengthening of cultural and linguistic consciousness. It was by means of Atlant that Slovenes took their rightful place alongside culturally and linguistically more developed nations; not all of whom, even those which were substantially larger nations than Slovenia, could claim to have produced such an extensive cartographic work.

The scientific literature is evidence that politically and culturally conscious people were aware of the importance of widespread support of the masses for the strengthening of the Slovene language. It was through books, written in the national language, that science and knowledge reached the ordinary person, who may not have known German but was already literate, since mandatory education had already had a long tradition in Slovenia. In this way the national consciousness touched a wide public which had prior to this nurtured only a local or regional sense of belonging. The scientific literature reached not only the intelligentsia but also the nationally conscious masses. The reach of Atlant can be seen in the number of copies printed. The first three sets of maps had a print run of 2000 copies each, while the second three had a run of 3000 copies each. For the sake of meaningful comparison, let us note that a facsimile of Atlant 130 years later had a print run of 1000 copies. Thus the print run of the original was enviable for those times, since science books even today usually have fewer copies printed. This gives us a very clear picture of Atlant as not just scientific literature, but much, much more. It served to awaken national consciousness, and played an important educational role. Members of the Matica slovenska came not just from the Slovene province of Carniola, but also Styria, Carinthia, and the Littoral as well as beyond. Territorially speaking, then, Atlant and other publications not only remained at the core of the national community, they also reached many more distant places.

Atlant brought the world closer to the people, and at the same time brought Slovenes closer to the world. Its intellectual position erased the border between »us « and »them « and gave Slovenes a status at least in the cultural sphere - equal to that of developed European nations. For small national communities language was the crucial factor which clearly distinguished them from others, and thus bolstered the justification for and the legalization of their existence. Hroch has called such a course of national emancipation the language-cultural program, led and guided by patriotic intellectuals (Hroch 1998). Publishing activity, organized to a great extent by the Matica slovenska, in just a few decades raised the status of the Slovene language to a language applied at all levels of education. 
Atlant and other publications helped consolidate the language from within and without. Due to the historical division of Slovene lands into different provinces, the language was also regionally defined, as were the people who spoke it. The majority of Slovene intellectuals were of peasant origin (Vodopivec 1998), which was connected with, among other things, the better opportunities for employment in government offices for people not of the aristocracy and members of non-Germanic language communities. Cigale's contribution to the standardization of the language for official and literary use represented the overcoming of regional particularisms. Intellectuals from different regions did speak different dialects, but they were especially aware of the importance of »mobilizing « the wider public and realized that it would be easier to accept a common standard Slovene language, a sort of »lingua franca «, than to adopt one of the regional variants and give it a universal character.

Atlant and other literature also reinforced the status of the Slovene language from the outside and in this way placed Slovenes on the cultural and linguistic map of the second half of the $19^{\text {th }}$ century. Atlant raised consciousness about »us « and clearly delineated »us « from »them «. This represented not only a distinction that Slovenes established relative to the German space, but also a search for their own space within the Slavic reality. It is true that many intellectuals of that time were quite favorably disposed towards the idea of pan-Slavism and that the construct of the South Slavs was being expressed with growing strength and clarity. But it was through Atlant and many other publications that the uniqueness and originality of the Slovene language became sharply crystallized. The proof of this can be seen in the fact that the idea of a joint Croatian-Slovene atlas was rejected when it was proposed, despite all the difficulties involved in the preparation of the first atlas of the world in the Slovene language, and the financial burdens that a joint project would have eased. In spite of a strong attachment to the South Slavic nations and to the Czechs, and especially the latter, who believed »... that we are almost certainly for all eternity without salvation from the Germanizing alligator whose throat has swallowed us ... (Čepič 1979, 478), Slovenes wanted to demonstrate the uniqueness of their language. This is shown also by Cigale's reflection in Scientific Terminology, that "... with Atlant we have somehow surpassed the other Austrian Slavs ... «(Cigale 1880, 4).

\section{Conclusion}

With the revolutionary year of 1848 began a new chapter of Slovene history. The ideas of United Slovenia and the related demands for the use of the national language stirred up and roused Slovene culture and politics. New newspapers in the Slovene language and newly established societies awakened and reinforced national consciousness, a process in which the Matica slovenska, founded in 1864, played an indispensable role. The fundamental purpose of its activity was the general education of Slovenes, which was realized through support for Slovene literature and the publishing of scientific and popular works. The Matica slovenska embarked on its mission with a work in geography, or more specifically, cartography. Among its earliest accomplishments was also Atlant, the first atlas of the world in the Slovene language.

Despite its extraordinary importance in awakening national consciousness and developing the mother tongue, Atlant did not enjoy the response it deserved among geographers, and over time it fell into almost total obscurity. Studies which were done as part of the preparation of the facsimile of Atlant showed that despite some justified criticisms, primarily of a linguistic nature, that were expressed when the atlas first came out, Atlant was an invaluable source for the research and analysis of Slovene geographical nomenclature. A number of geographical names in the atlas were translated into Slovene or Slovenized for the first time. The geographical, linguistic and political conditions that Slovenes lived in at the time can be seen in the ways in which the names appearing in Atlant were adapted. Atlant also shines a light on the relationships between Slovene, German, and other Slavic languages, which were a factor in the degree to which geographical names were Slovenized, and on the choice of language used as a basis for translation or Slovenization of the names.

Atlant thus enriched the Slovene language more than a century ago with a considerable number of Slovenized and translated geographical names, many of which have been preserved to this day in contemporary Slovene. In an age of globalization, when there is a strong tendency for English to dominate the world, this is something of great value and importance.

Geography is extremely important for Slovenia as a small country, since with the help of geography it would like to become as widely known as possible on today's map of the world. Geography has been 
important for Slovenes throughout their history as a nation, contributing as it has to the establishment and the preservation of Slovene national consciousness through the publications of works such as Atlant. In this way Slovene geography has also made its contribution to the preservation of diversity, one of the most important values of the European Union.

\section{References}

Anderson, B. 1995: Imagined Communities: Reflections on the Origin and Spread of Nationalism. London, New York.

Baskar, B. 2004: Krajevna imena med kolonializmom in etničnim nacionalizmom. Gledališki list SNG Drama 84. Ljubljana.

Berk, S. 1998: (Ne)prepoznavnost Slovenije in njena zamenljivost s Slovaško. Geografski obzornik 45, 1. Ljubljana.

Bohinec, V. 1925: Razvoj geografije v Slovencih. Geografski vestnik 1. Ljubljana.

Cigale, M. 1880: Znanstvena terminologija s posebnim ozirom na srednja učilišča = Deutsch-slowenische wissenschaftliche Terminologie. Ljubljana.

Claval, P. 1998: An Introduction to Regional Geography. Oxford, Malden.

Cohen, S. B., Kliot, N. 1992: Place-names, in Israel's Ideological Struggle over the Administered Territories. Annals of the Association of American Geographers 82. Oxford.

Cosgrove, D. 1999: Introduction: Mapping Meaning. Mappings. London.

Craig, R. B. 2000: Cartography and Power in the Conquest and Creation of New Spain. Latin American Research Review 35. Austin.

Čepič, Z. 1979: Zgodovina Slovencev. Ljubljana.

Dörflinger, J., Hühnel, H. 1995: Atlantes Austriaci. 1. Band, 1. Teilband: Österreichische Atlanten 1561-1918. Wien. Köln, Weimar.

Dorling, D., Fairbairn, D. 1997: Mapping: Ways of Representing the World. Harlow, London.

Fridl, J. 1995: Zgodovinski razvoj kartografije. Geografski obzornik 42, 1. Ljubljana.

Fridl, J., Kladnik, D., Orožen Adamič, M., Perko, D. 1998: Geografski atlas Slovenije. Ljubljana.

Fridl, J., Kladnik, D., Orožen Adamič, M., Perko, D. 2001: National atlas of Slovenia. Ljubljana.

Fridl, J., Kladnik, D., Orožen Adamič, M., Perko, D., Urbanc M. 2005: Atlant. Ljubljana.

Fridl, J. 2005: Kartografska podoba zemljevidov 19. stoletja. Atlant. Ljubljana.

Gams, I. 1991: Analiza imen za obalno regijo. Annales 1, 1. Koper.

Gellner, E. 1983: Nations and Nationalism. Ithaca, NY.

Granda, S. 2001: Iz kulturnega v politični narod. Od sanj do resničnosti: razvoj slovenske državnosti. Ljubljana.

Grdina, I. 1999: Od rodoljuba z dežele do meščana. Ljubljana.

Harley, J. B. 1992: Deconstructing the Map. Writing Worlds: Discourse, Text and Metaphor in the Representation of Landscape. London, New York.

Harley, J. 2001: The New Nature of Maps: Essay in the History of Cartography. Baltimore.

Harley, J. B. 2002: Maps, Knowledge and Power. The Iconography of Landscape. Cambridge.

Hroch, M. 1985: Social Preconditions of National Revival in Europe: a Comparative Analysis of the Social Composition of Patriotic Groups among smaller European Nations. Cambridge.

Hroch, M. 1995: National Self-determination from a Historical Perspective. Canadian Slavonic Papers 37. Ottawa.

Hroch, M. 1998: Programme und Forderungen nationaler Bewegungen: Ein europäischer Vergleich. Entwicklung der Nationalbewegungen in Europa 1850-1914. Berlin.

Ilustrirana zgodovina Slovencev. Ljubljana, 1999.

Jesenko, J. 1865: Zemljepisna začetnica za gimnazije in realke. Gorica.

Jett, S. C. 1997: Place-naming, Environment, and Perception among the Canyon de Chelly Navajo of Arizona. Professional Geographer 49, 4. Hamilton.

Kadmon, N. 2000: Toponymy - The Lore, Laws and Language of Geographical Names. New York.

Kladnik, D. 2005: Zemljepisna imena v Atlantu in njihov pomen za sodobno imenoslovje. Atlant. Ljubljana. Kovačič-Peršin, P. 2000: Zorenje slovenske narodne zavesti in identitete. 2000 127/128. Ljubljana. 
Lilley, K. D. 2000: Landscape Mapping and Symbolic Form. Drawing as a Creative Medium in Cultural Geography. Cultural Turns, Geographical Turns: Perspectives on Cultural Geography. Englewood Cliffs.

Majaron, D. 1887: Matej Cigale. Slovan 15, 16. Ljubljana.

Majaron, D. 1889: Matej Cigale. Slovenski pravnik. Ljubljana.

McKenzie, D. F. 1986: Bibliography and the Sociology of Texts. London.

Melik, V. 1993: Nemško-slovenski odnosi. Enciklopedija Slovenije 7. Ljubljana.

Melik, V. 1997: Slovenska matica. Enciklopedija Slovenije 11. Ljubljana.

Melik, V. 1998: Ideja Zedinjene Slovenije 1848-1991. Slovenija 1848-1998: iskanje lastne poti. Maribor.

Merklas, W. 1846: Malý příruční atlas wšwch části Zemé. Praha.

Moritsch, A. 1997: Narodna identiteta: nujnost ali anahronizem? Avstrija, Jugoslavija, Slovenija. Slovenska narodna identiteta skozi čas. Ljubljana.

Myers, G. A. 1996: Naming and placing the other: power and the urban landscape in Zanzibar. Tijdschrift voor Economische en Sociale Geografie 87.

Nash, C. 1999: Irish placenames: Post Colonial Locations, Transactions of the Institute of the British Geographers 24. Oxford, Malden.

Navratil, I. 1894: Matej Cigale. Koledar Družbe sv. Mohorja: za navadno leto. Celovec.

Ó Maolfabhail, A. 1992: The background and present role of the Placenames Branch of the Ordnance Survey. The Placenames of Ireland in the Third Millennium. Dublin.

Orožen Adamič, M., Perko, D., Kladnik D. 1995: Krajevni leksikon Slovenije. Ljubljana.

Paasi, A. 1991: Deconstructing Regions: Notes on the Scales of Human Life. Environment and Planning A 23. London.

Paasi, A. 2003: Region and Place: Regional Identity in Question, Progress in Human geography 27, 4. London

Perko, D., Orožen Adamič M. 1998: Slovenija - pokrajine in ljudje. Ljubljana.

Perko, D. 2001: Analiza površja Slovenije s stometrskim digitalnim modelom reliefa. Geografija Slovenije 3. Ljubljana.

Pickles, J. 1992: Texts, Hermeneutics and Propaganda Maps. Writing Worlds: Discourse, Text and Metaphor in the Representation of Landscape. London, New York.

Pile, S., Thrift, N. 1995: Mapping the subject. Mapping the Subject: Geographies of Cultural Transformation. London.

Prunk, J. 2000: Zedinjena Slovenija, bistvo slovenskega narodnopolitičnega programa. 2000 127/128. Ljubljana.

Sauer, C. O. 1966: On the Background of Geography in the United States. Heidelberger Geographische Arbeiten 15. Heidelberg.

Seton-Watson, H. 1980: Nacije i države: ispitivanje porijekla nacija i politike nacionalizma. Zagreb.

Slovenski narod 110, 14. maj 1873. Ljubljana.

Slukan Altić, M. 2003: Povijesna kartografija: Kartografski izvori u povijesnim znanostima. Samobor.

Soini, K. 2001: Exploring Human Dimensions of Multifunctional Landscapes through Mapping and Map-making, Landscape and Urban Planning 57. Amsterdam, Oxford, New York, Tokyo.

Šaver, B. 2005: Nazaj v planinski raj: Alpska kultura slovenstva in mitologija Triglava. Ljubljana.

Šumrada, J. 2005: Politična in družbena podoba druge polovice 19. stoletja. Atlant. Ljubljana.

Urbanc, M., Gabrovec, M. 2005: Krajevna imena: poligon za dokazovanje moči in odraz lokalne identitete. Geografski vestnik 77, 2. Ljubljana.

Vallières, A. 1992: The administrative framework of a central toponymyc agency. Ottawa.

Vodopivec, P. 1998: Vloga slovenskih intelektualcev pri emancipaciji Slovencev. Slovenija 1848-1998: iskanje lastne poti. Ljubljana.

Yeoh, B. 1996: Street-naming and Nation Building: Toponymic Inscriptions of Nationhood in Singapore. Area 28. London.

Zeměpisný atlas podle nejnowějších pramenůw a pomůcek. Praha, 1842. 


\section{Atlant in slovenska nacionalna zavest $\mathrm{v} 2$. polovici 19. stoletja}

UDk: $912.44(497.4) " 19 "$

COBISS: 1.01

IZVLEČEK: Geografska literatura je pomembno prispevala k razvijanju nacionalne zavesti Slovencev v 19. stoletju in k utrjevanju slovenske identitete po osamosvojitvi Slovenije leta 1991. Tipičen primer takšne geografske publikacije je Atlant, prvi atlas sveta v slovenskem jeziku, ki je izhajal med letoma 1869 in 1877 in sledil ideji Zedinjene Slovenije, s katero so v tem prelomnem času Slovenci, večinoma vključeni v Avstro-Ogrsko, kot narod prvič odločneje stopili na politično prizorišče Evrope. Številna zemljepisna imena so bila prvič prevedena ali podomačena v slovenski jezik. V značilnostih prirejanja tujih zemljepisnih imen se kažejo geografske, jezikovne in politične razmere, v kakršnih so živeli Slovenci, pa tudi takratna razmerja med slovenščino, nemščino in slovanskimi jeziki. Tudi ponovna izdaja Atlanta leta 2005 je povezana s prelomnim časom, saj je izšla po osamosvojitvi Slovenije in njeni vključitvi v Evropsko zvezo, ko mlada država išče svojo identiteto med vsemi državami sveta.

KLJUČNE BESEDE: historična geografija, kartografija, atlas, zemljevid, Slovenija, Avstro-Ogrska, zemljepisno ime, endonim, eksonim, identiteta, narodotvornost, nacionalna zavest.

Uredništvo je prejelo prispevek 4. avgusta 2006.

NASLOVI:

\section{Mimi Urbanc, mag.}

Geografski inštitut Antona Melika

Znanstvenoraziskovalni center Slovenske

akademije znanosti in umetnosti

Gosposka ulica 13, SI - 1000 Ljubljana,

Slovenija

E-pošta:mimi@zrc-sazu.si

Jerneja Fridl, mag.

Geografski inštitut Antona Melika

Znanstvenoraziskovalni center Slovenske

akademije znanosti in umetnosti

Gosposka ulica 13, SI - 1000 Ljubljana,

Slovenija

E-pošta: jerneja@zrc-sazu.si

\section{Drago Kladnik, mag.}

Geografski inštitut Antona Melika

Znanstvenoraziskovalni center Slovenske akademije znanosti in umetnosti

Gosposka ulica 13, SI - 1000 Ljubljana, Slovenija

E-pošta: drago.kladnik@zrc-sazu.si

Drago Perko, dr.

Geografski inštitut Antona Melika

Znanstvenoraziskovalni center Slovenske

akademije znanosti in umetnosti

Gosposka ulica 13, SI - 1000 Ljubljana,

Slovenija

E-pošta: drago@zrc-sazu.si

\section{Vsebina}

1 Uvod

2 Moč, vedenje in kartografija kot inštrumenti

kulturne identitete in narodne zavesti

Zgodovinsko ozadje in prostor: položaj Slovencev znotraj večnacionalne monarhije

Matica slovenska - preseganje deželnih meja in njeno kulturno delovanje 


\section{Uvod}

"... Ko iščemo sled o enotnem slovenskem ljudstvu, nam pot kaže predvsem jezikovna sled. Prav skupna jezikovno kulturna zavest je tudi porodila idejo poenotenja slovenskega narodnega telesa. Ideja združevanja Slovencev je izrazito kulturni projekt in taka ostane še dolgo po tem, ko je že formulirana tudi kot politični program Zedinjene Slovenije ... (Kovačič-Peršin 2000, 27).

V članku predstavljamo vlogo in pomen geografske literature v slovenskem jeziku za obujanje in razvijanje slovenske narodne zavesti v drugi polovici 19. stoletja. Proces oblikovanja kulturne identitete prek književnosti se je med Slovenci začel z reformacijo in se razcvetel po valu meščanskih revolucij, ko so se v Habsburški monarhiji, aristokratski absolutistični državi, začela uveljavljati ustavna in demokratična načela. Pri tem sta pomembna poudarjeni nacionalni vidik in z njim povezana pravica do uporabe domačih jezikov, kar je majhnim narodom v večnacionalnih državah omogočilo kulturni razvoj, ki je bil temelj oblikovanja narodne zavesti. Razvoj narodne zavesti postavljamo v širši okvir Habsburške monarhije in jo razlagamo kot mrežo stikov, vplivov, zgledov in sodelovanja med nemškimi, avstrijskimi, češkimi in slovenskimi deželami.

Zgodovinski vpliv geografske literature na krepitev narodne zavesti prikazujemo na primeru Atlanta, prvega atlasa sveta v slovenskem jeziku, ki je v šestih snopičih s po tremi listi izhajal med letoma 1869 in 1877. Zemljevidi so učinkovita grafična sredstva, saj se ponašajo z veliko sporočilno vrednostjo in pomagajo oblikovati odnos do sveta, ob tem pa izpričujejo tudi pogled izdelovalcev, založnikov, lahko tudi določenega naroda na bližnjo in daljno okolico, lahko tudi na ves svet. Zato je razvoj zemljevidov skozi zgodovino posredno povezan tudi z vzponom nacionalnih držav (Harley 2002). Pri tem imajo posebno vlogo zemljepisna imena, ker celovito dopolnjujejo pogled na okolje in svet, v katerem družba živi. Zemljepisna imena so tesno povezana z jezikovno stvarnostjo, kar velja tako za endonime kot za eksonime. Sporočilnost zemljepisnih imen v obravnavanem atlasu je toliko večja, ker je bil njegov prireditelj Matej Cigale po poklicu jezikoslovec. Zaradi pomanjkljivih zgledov v takrat še redki in nedodelani strokovni literaturi so zemljepisna imena $\mathrm{v}$ Atlantu rezultat prizadevnega intelektualnega snovanja in nikakor ne plod nekritičnega povzemanja iz sorodnih publikacij. Cigale kot osebnost je bil prototip narodno zavednega intelektualca 19. stoletja. Njegova biografija dodobra osvetljuje tudi družbeno podobo tistega časa.

$\mathrm{V}$ članku želimo prvi svetovni atlas v slovenskem jeziku predstaviti kot vir za analiziranje prostora, kulture in časa, v katerem je nastal. V novi luči želimo osvetliti in ovrednotiti njegovo vlogo in pomen za razvoj narodne zavesti Slovencev. Osredotočili smo se na razvoj zavedanja narodnega telesa kot naroda, na vlogo jezika pri njegovem oblikovanju in na kulturni vidik tega procesa. Raziskava je zajela tako tehnični kot vsebinski vidik, pri čemer je pomembno, kaj zemljevidi prikazujejo in na kakšen način to izražajo. Prvi vidik se nanaša zlasti na prostorske tokove, povezane s Slovenci, in njihovo časovno umestitev. Drugi vidik je bolj zapleten in dvoumen, saj zahteva pravilno branje in razumevanje zemljevidov v Atlantu, še zlasti zemljepisnih imen. Zanimala nas je predvsem kognitivna raven Atlanta, ki nakazuje položaj Slovencev $\mathrm{v}$ večnacionalni državi ter razmerje med slovenščino in drugimi jeziki; ne le z nemščino, ampak tudi s češčino in z drugimi slovanskimi jeziki. Nadalje želimo predstaviti Atlant kot medij, prek katerega se je lokalno oziroma nacionalno prenašalo v zunanji, to je mednarodni in globalni svet, tokovi so seveda tekli tudi v obratni smeri. Z njegovo pomočjo so se brisale meje med slovensko in širšo skupnostjo, vendar so se obenem tudi na novo vzpostavljale. Pri tem je treba razumeti tudi strategije, s katerimi je Matica slovenska, ki je izdajala Atlant, pridobivala svoje bralstvo, saj so pomagale razširjati čut zavedanja oziroma pripadnosti svoji skupnosti.

\section{Moč, vedenje in kartografija kot inštrumenti kulturne identitete in narodne zavesti}

Zemljevidi so že dolgo povezani z geografskim delom, vendar zlasti kot orodje za prikazovanje najrazličnejših dognanj. Od tod izhaja tradicionalni pogled nanje kot na abstrakcijo realnosti; odražajo namreč objektivno informacijo o okolju, ki nas obdaja (Soini 2001). Kadar so sami predmet preučevanja, so običajno 
v ospredju tehnični in tehnološki vidiki njihove izdelave. Redkeje so uporabljeni in razumljeni kot »besedilo« oziroma družbeno proizvedena oblika védenja. V tem primeru so zemljevidi rezultat stopnje družbenega in kulturnega razvoja nekega naroda in odsevajo avtorjev oziroma izdelovalčev pogled na svet (Pile in Thrift 1995; Dorling in Fairbairn 1997; Cosgrove 1999). Pri starejših zemljevidih se odpira nova dimenzija zgodovinskega dokumenta, ki razkriva politično in kulturno podobo obdobij, v katerih so nastajali. Tako dobivajo starejši zemljevidi pomembno vlogo pri preučevanju zgodovinskih dejstev; $\mathrm{v}$ našem primeru je še posebej pomembna njihova vloga pri vzponu sodobnih narodnih držav, o čemer je pisal že Harley (2002).

Harleyjeva spoznanja so za nas uporabna le v omejenem obsegu. Njegova razmišljanja o moči kartografije se z določenimi modifikacijami da vpeti tudi v srednjeevropski zgodovinski prostor. Slovenska realnost je bila nekoliko drugačna. Pri nas je šlo za vzpon narodnega gibanja, saj je bil celoten srednjeevropski prostor z vidika formiranja nacionalnih držav precejšen zgodovinski zamudnik; nastajati so začele šele, ko so v 1 . svetovni vojni razpadli štirje veliki nadnacionalni imperiji, habsburški, nemški, ruski in turški, ki so številne narode dolgo vklepali v svoj »ljubeči objem«. Kljub precejšnjim razlikam med obema procesoma lahko vendarle potegnemo določene vzporednice in $\mathrm{z}$ določenimi pridržki uporabimo tudi Harleyjeva dognanja.

Zemljevid je rezultat dveh skupin dejavnikov: izdelave in uporabe. Prvo skupino sestavljajo idejni vodja oziroma njegov založnik in izdelovalec. Z vidika uporabe so v ospredju kulturne, družbene in politične razmere ter želje in pričakovanja javnosti (Craig 2000). Pri izdelavi je pomembna ideja, ki je vodila založnika oziroma izdelovalca. Izdelovalec običajno le uresniči želje in zahteve naročnika. Ravno zaradi nje imajo zemljevidi veliko sporočilno vrednost. »... na zemljevidu ni praznin... «, je trditev, na kateri gradi Harley svoje dojemanje zemljevidov (Harley 2001). Njegovo delo temelji na prepričanju, da natančno preučevanje kartografske podzavesti in njenih družbenih temeljev lahko na zemljevidih razkrije skriti načrt. Ravno tisto, kar je na prvi pogled nevidno, daje zemljevidom moč, tako politično kot kulturno. Harley je torej zemljevide dojemal kot predmet moči in vedenja, zato je tudi njihovo ustvarjanje razumel kot odsev političnega sistema.

Harleyjev pogled na ideološko moč zemljevidov je torej mogoče uporabiti tudi za naš namen, to je analiziranje zemljevidov kot sestavnega dela razvoja narodne zavesti in s tem oblikovanja narodne identitete. Najprej je zemljevid treba razumeti kot vrsto jezika, ki se ga, »napisanega « za določeno javnost, da prevajati in razlagati. Naslednji vidik je ikonologija, ki razkriva tako globok simbolni kot tudi nadnaraven, literarni pomen. Nenazadnje pojmujemo kartografijo kot obliko znanja. Harley je svoje razumevanje zemljevidov nadgradil s trditvijo, da njihov izdelovalec oziroma naročnik z izdelkom vselej manipulira z njegovimi uporabniki. Po njegovem zemljevidi prikazujejo politične in kulturne težnje avtorja oziroma naročnika (Harley 2001). V primeru Atlanta so bila najmočnejše avtorjevo oziroma prirediteljevo orodje zagotovo zemljepisna imena, saj je prek njih kreiral jezikovno politiko in ob tem slovenski jezik postavil ob bok drugim, v kartografiji že uveljavljenim evropskim jezikom v deželah z razvito kartografijo.

Jezikovna plat zemljevidov na eni strani kaže stanje oziroma razvojno stopnjo jezika, na drugi pa pogled njihovih izdelovalcev in družbe na prostor in čas, v katerem zemljevidi nastajajo. Zemljepisna imena so ob jezikoslovju tudi priljubljena tema geografije, še zlasti historične, saj so tako stvarna kot metaforična, tako dejanska kot simbolna, predvsem pa odpirajo vselej aktualno vprašanje moči, kulture, lokacije in identitete (Nash 1999). Obstaja vrsta opredelitev zemljevidov in pogledov nanje (Sauer 1966; Jett 1997; Claval 1998). Za pričujoči članek je pomembna njihova vloga medija, prek katerega se razvija odnos ljudi do okolja, v katerem živijo, s tem pa tudi njihova identiteta (Gams 1991; Yeoh 1996; Jett 1997, Berk 1998; Nash 1999; Urbanc in Gabrovec 2005). Prek toponimov se pogosto izvaja psihološki boj za prilaščanje prostora (Cohen in Kliot 1992; Myers 1996; Harley 2001; Baskar 2004), bodisi za kolonialno, fizično prilaščanje bodisi za duhovno.

V primeru maloštevilnih narodov znotraj večnacionalnih držav prilaščanje prostora pojmujemo na mentalni ravni, saj gre za prilastitev lastnega prostora in njegovega preoblikovanja $\mathrm{v}$ nacionalni prostor. Anderson (1995) ta proces imenuje oblikovanje zamišljene skupnosti, kot temeljni mejnik tega procesa pa izpostavlja tisk. Tako si je na primer, če spet posežemo v kolonialno zgodovino in vlečemo vzporednice z narodnimi gibanji v srednji Evropi, v koloniziranih deželah domača inteligenca zamislila lastne narodne skupnosti takrat, ko so ljudje lahko začeli prebirati časopisje v svojem domačem jeziku (Anderson 1995). Večina definicij nacionalizma poudarja politični vidik (Gellner 1983; Anderson 1995), vendar je bil ta proces oblikovanja drugačen pri tistih narodnih skupnostih, ki niso imele lastnega vladajočega razreda, niso 
nikoli živele v neodvisni državni tvorbi, ki bi se ujemala z njihovim naselitvenim prostorom, niso poznale nepretrgane tradicije intelektualnega ustvarjanja v narodnem jeziku, ali pa je bil narodni jezik izkoreninjen ali močno degeneriran (Hroch 1985). V navedenih primerih gre za »oživitev« zatiranega majhnega naroda s pomočjo kulturnega ustvarjanja, pri čemer majhnost ni mišljena v številčnem smislu. Po Hrochu je lahko ta proces razmeroma dolgotrajen, ker prehod $\mathrm{v}$ politično fazo zaradi različnih okoliščin ni mogoč. Tudi kadar se politične zahteve lahko uresničijo, se običajno najprej materializirajo v avtonomiji, ne pa neposredno v neodvisnosti (Hroch 1995). Tu je treba Hrochovo razglabljanje nadgraditi: res je, da je bilo v prvem obdobju narodno prebujenje predvsem kulturno, vendar so ga spodbudili določeni politični vzgibi. Političen značaj ima že samo po sebi, ker ga je omogočila šele določena politična situacija. V primeru Slovencev velja, da je bilo mogoče prepoznati politične zahteve v podtonih (Vodopivec 1998).

Dejstva, ki zavirajo kulturno emancipacijo majhnih narodov, lahko razčlenimo na notranja in zunanja. Prva izhajajo iz samega naroda. V primeru Slovencev je bila najpomembnejša nepopolna družbena struktura, saj ni bilo domačega vladajočega razreda oziroma je bil slabo zastopan, pa tudi drugi razredi in družbene skupine so bile atipično zastopane (Hroch 1985). Zunanja dejstva so tista, ki izhajajo iz države, znotraj katere narod živi. V našem primeru je bila to Habsburška monarhija. Sklop dejavnikov, ki so odločilno vplivali na življenje malih narodov, lahko imenujemo hegemonija vladajočega razreda, ki jo je spremljala določena stopnja asimilacije. V takih razmerah je bila kulturna identiteta tista, ki je gradila narodno identiteto, ta pa je najpomembnejša za razvoj modernega naroda. Identiteta je širok pojem, ki razkriva kolektivne predstave, te pa vzpostavljajo zavest o narodni skupnosti. Če upoštevamo humanistično dimenzijo identitete, potem gre za dialektični sistem, ki združuje dva vidika, in sicer »mi« in »oni«. V našem primeru ta dihotomija ne zajema samo dvojnosti na horizontalni ravni, ampak tudi na vertikalni, kjer gre za razmerje med konceptoma »od spodaj« in »od zgoraj« (Paasi 1991 in 2003). Pri tem je pomembno, da gre v bistvu za razmerje moči oziroma za mentalne meje. Tako je koncept »oni« dodatno obtežen s konceptom »od zgoraj«.

Pri postavljanju dejanskih in mentalnih meja se kartografija in narodna zavest tesno prepletata. Lilley (2000) trdi, da je izdelava zemljevida ustvarjalen proces, ki se lahko primerja s pisanjem besedila, da je zrcalo dojemanja okolja in prostorske predstave ljudi. Zato je kartografija tudi način preučevanja, kaj je naš zunanji svet in kaj naš notranji svet. V tej luči je kartografija tista, ki postavlja meje in jih obenem pomaga rušiti oziroma zaobiti, saj prenaša intelektualni in svetovnonazorski pogled naročnika in izdelovalca zemljevida v kontekst širše skupnosti. Gre za vprašanje prenašanja podobe, kot sta si jo zamislila naročnik in avtor, $\mathrm{v}$ širši svet, in s tem doseganja globlje sporočilnosti. Tiskanje zemljevidov s slovenskimi imeni je bilo namenjeno predvsem brisanju razlik med »mi« in »oni«, saj je slovensko narodno skupnost postavilo v družbo ostalih narodov in jo soočilo z njihovim kulturnim, narodnim in političnim razvojem, obenem pa je jasno poudarilo predstavo o »mi« in slovenski narod obvarovalo pred zlitjem z večjimi narodnimi skupnostmi.

\section{Zgodovinsko ozadje in prostor: položaj Slovencev znotraj večnacionalne monarhije}

Slovenci vse od zgodnjega srednjega veka nismo bili politično povezani v nacionalni državi. Svoje biti smo se začeli zavedati v obdobju protestantizma, ko smo dobili prve knjige, in še zlasti v času narodnega preporoda $\mathrm{v}$ drugi polovici 18. stoletja in Ilirskih provinc na začetku 19. stoletja. Težnje po narodovi samobitnosti so še bolj prišle do izraza v revolucionarnem letu 1848.

Prej je imelo slovensko narodno gibanje izključno kulturni značaj. Etnonim Slovenec se je zlasti v tridesetih in štiridesetih letih 19. stoletja vse bolj uveljavljal in nadomeščal uveljavljene oznake za pripadnike slovenskega naroda (Wenden, Kranjci). Čeprav je za ves s Slovenci poseljen prostor že pred letom 1848 obstajala oznaka Slovenija, poimenovanje, ki ga niso poznale ne geografija ne zgodovina ne obstoječa upravna členitev, se je v gospodarsko, kulturno in politično šibko integrirani družbi sodobna nacionalna zavest le počasi uveljavljala (Ilustrirana zgodovina Slovencev 1999).

Leta 1848 so Slovenci na Dunaju formulirali program Zedinjene Slovenije. V njem so zahtevali upravno ali politično združeno slovensko narodnostno ozemlje, ki naj bi nastalo s predvideno preobrazbo avstrijskega cesarstva $v$ meščansko parlamentarno monarhijo in z notranjo upravno preureditvijo države. Program je Slovence navdajal z upanjem, da bo nastala večja upravna enota Slovenija, ki bo zajela vse slovensko 
etnično ozemlje. V ustanovnem razglasu društva Slovenija smo zahtevali, »... da se politiško razkropljeni narod Slovencev na Kranjskim, Štajerskim, Primorskim in Koroškim kakor jeden narod v eno kraljestvo Slovenija zedini...« (Ilustrirana zgodovina Slovencev 1999, 227). Program Zedinjene Slovenije se je povezoval z zahtevami po jezikovnih pravicah, in sicer po enakopravnosti jezika v primerjavi z ostalimi (nemškim, italijanskim) in njegovo uporabo $\mathrm{v}$ šolah, uradih in na sodiščih; pojavila se je tudi zahteva po slovenski univerzi.

Program je kartografsko podkrepil Zemljovid slovenske dežele in pokrajin, ki ga je izdal pravnik, geograf in politik Peter Kozler (1824-1879), po rodu kočevski Nemec. Na njem je vrisal slovensko etnično mejo in jo utemeljil v spremni knjižici. Zemljevid je bil natisnjen že leta 1853, izšel pa je šele osem let pozneje, leta 1861, saj so ga prizadele sankcije Bachovega neoabsolutizma, oziroma utemeljitev, da prikazuje neobstoječo politično tvorbo. Zemljovid Slovenske dežele in pokrajin, ki je doživel več ponatisov, zaradi nacionalnega naboja še vedno velja za eno od svetinj slovenstva.

Slika 2: Kozlerjev Zemljovid slovenske dežele in pokrajin, natisnjen leta 1853 je prvi zemljevid z začrtanim slovenskim etničnim ozemljem. Zaradi politične spornosti je bil objavljen šele 8 let pozneje.

Glej angleški del prispevka.

Vendar je bil tabor, ki je program Zedinjene Slovenije oznanjal in stal za njim, maloštevilen in šibek. Prav nobenega zaupanja ni doživel med kmečkim življem, med slovenskim meščanstvom je naletel na mlačen sprejem, saj se je mnogim, ki so se zavedali svojih slovenskih korenin, zdel preveč radikalen. Mnoge je motila tudi »ilirska« usmerjenost dela voditeljev narodnega gibanja, ki so se zavzemali za združitev s Hrvaško. Še manj razumevanja za program Zedinjene Slovenije je bilo seveda med nemškim prebivalstvom v mestih in trgih.

Cigaletov Atlant, ki je v določenem oziru nadaljevanje Kozlerjevega zemljevida, je našo tedanjo širšo domovino anahronistično, morda tudi s politično tendenco, imenoval Avstrija: zemljevid, ki je izšel kot tretji v prvem snopiču, je bil namreč natisnjen leta 1869, ko se je država že dve leti uradno imenovala Avstro-Ogrska. Ravnokar se je izvila iz dveh zaporednih obdobij resne notranjepolitične krize, ki sta ju povzročila huda poraza $\mathrm{v}$ vojnah $\mathrm{v}$ letih 1859 in 1866, s katerima je habsburški dvor nameraval preprečiti zedinjenje Italije in Nemčije. Že prva vojaška katastrofa konec petdesetih let je povzročila tektonski premik v notranjepolitičnem življenju Habsburške monarhije. Odzvonilo je absolutističnemu režimu, začelo se je ustavno ter državnozborsko in deželnozborsko politično življenje, ki pa še dolgo ni bilo demokratično. Z njim se je začela nova stopnja v razvoju slovenskega narodnega gibanja, ki jo je Bogo Grafenauer upravičeno imenoval »afirmacija slovenske narodne celote« (Čepič 1979, 964).

Slika 3: Izsek iz 3. zemljevida Atlanta, ki je izšel konec leta 1869, z naslovom »Avstrija«, kljub temu, da se je naša skupna država takrat imenovala Avstro-Ogrska.

Glej angleški del prispevka.

Za sodobnega Slovenca je pomenljiv pogled na mozaik zgodovinskih dežel, v katerih smo tedaj živeli tako nam postaneta razumljivejši temeljni zahtevi našega političnega življenja v obdobju taborov (1868-1871), zedinjena Slovenija in slovenski uradovalni jezik. S Slovenci poseljeno ozemlje se je delilo na dežele Kranjsko v osredju, Koroško na severu, Štajersko na severovzhodu in Primorsko z Istro na zahodu. Kljub temu da so zunaj meja matične države ostali Beneški Slovenci in Rezijani, je bila to za slovensko skupnost najbolj ugodna razmejitev proti Italiji, ki je vztrajala od leta 1866 do 1 . svetovne vojne. Kranjska in Primorska sta zajemali glavnino slovenskega nacionalnega ozemlja, Koroška in Štajerska pa sta segali daleč prek takratnega slovenskega poselitvenega ozemlja v osrčje zdajšnje Republike Avstrije. Slovenci v Prekmurju, pokrajini na levem bregu reke Mure, so spadali neposredno v ogrski del monarhije. Prekmurje je bilo, tako kot še danes, protestantsko, ostale slovenske dežele pa so bile katoliške.

Zaradi nemškega pritiska se je slovenska narodnostna meja na severu vseskozi postopoma pomikala proti jugu. Sredi 19. stoletja je obstajal le še majhen osamljeni otok slovenstva južno pod Grossglocknerjem, izgubljena je bila prevlada v zgornji Ziljski dolini in etnična meja se je začela približevati Dravi. Slovenski živelj je prevladoval le na podeželju, v mestih pa se je mešal z nemškim prebivalstvom, na Primorskem ( $z$ delno izjemo Trsta in Gorice) pa italijanskim prebivalstvom. Zaradi gospodarske moči so bila prav mesta prizorišča srditega boja za narodno prevlado, zato je razumljivo, da so se v njih osredotočale tudi ustanove, pomembne za narodni razvoj. 
Velik gospodarski dosežek je pomenila izgradnja železniške proge Dunaj-Trst, ki je leta 1857 slovenske dežele povezala z gospodarsko bolj razvitim osrčjem monarhije. Pred izbruhom gospodarske krize leta 1873 so se na Slovenskem oblikovale prve večje delniške družbe. Razmeroma uspešno so se razvijali premogovništvo, železarstvo, pivovarstvo, papirništvo, usnjarstvo, opekarstvo in gradbeništvo, vendar je bil domači kapital razmeroma šibek. Sredi 19. stoletja se je močno okrepila državna birokracija, tako civilna kot vojaška. Porast uradništva je odprl vrata zaposlovanju večjega števila ljudi. Tudi v sicer plemiškem avstro-ogrskem uradništvu se je močno povečal delež oseb iz srednjega razreda: od $0 \%$ leta 1804 je narasel na kar $55 \%$ leta 1878 (Anderson 1995). Obenem se je povečala tudi vloga trgovske in industrijske buržoazije. Za Slovence je to pomenilo, da so tudi oni postajali podjetniki in se zaposlovali v državni upravi. S tem pa je začela krepiti tudi moč slovenstva. Vendar je slovenska družba ostala večinoma agrarna. Na ozemlju zdajšnje Republike Slovenije se je leta 1857 s kmetijstvom preživljalo $83 \%$ ljudi, leta 1880 še $81 \%$, pa tudi leta 1910 še vedno zajetnih $67 \%$. Ker je bilo kmetijstvo zaostalo in razdrobljeno, delovnih mest zunaj njega pa je vseskozi kronično primanjkovalo, se je pojavilo množično izseljevanje, zlasti v Ameriko. Ker je izseljevanje pobralo več kot 50 \% naravnega prirastka, se je delež Slovencev v Avstro-Ogrski vseskozi zmanjševal (Ilustrirana zgodovina Slovencev 1999).

Že leta 1861, ko je Franc Jožef I. s februarskim patentom preuredil avstrijsko polovico monarhije, so bile ustanovljene slovenske čitalnice v Trstu, Mariboru in Celju; do leta 1869 se jih je namnožilo kar 57. V njih so se zbirali narodno zavedni izobraženci, slovenska mestna in trška gospoda ter podeželski veljaki pa tudi drobno meščanstvo; kmečki stan so v omejenem obsegu privabljale le ponekod, zlasti na Primorskem. Prirejale so številne tako imenovane besede z igrami, recitacijami, petjem, koncertnimi točkami, predavanji in govori, veselicami in plesi. Središče vseslovenskega kulturnega in političnega delovanja je začela postajati Ljubljana, glavno mesto osrednje s Slovenci poseljene habsburške dedne dežele, vojvodine Kranjske. Konec šestdesetih let 19. stoletja je imela njena čitalnica blizu 300 članov in je bila matična vsem drugim čitalnicam. V mestu je imelo svoj sedež po češkem vzoru oblikovano telovadno društvo Južni sokol, ustanovljeno leta 1863. Leto pozneje je bila v Ljubljani ustanovljena Matica slovenska, prvo domače laično društvo za izdajanje znanstvenih, poljudnih in drugih knjig v slovenskem jeziku, dve leti zatem pa Dramatično društvo, predhodnik Slovenskega narodnega gledališča (Šumrada 2005).

Ljubljana je bila v tem času nedvomno tudi sedež konservativno, staroslovensko usmerjene politike pod vodstvom Janeza Bleiweisa (1808-1881) in njegovih časopisov: slovenskih Novic gospodarskih, obertnijskih in narodskih (1843-1902) ter nemškega Triglava (1865-1870). Mladoslovenska politična opcija z vodjema skladateljem in pesnikom Miroslavom Vilharjem (1818-1871) ter pisateljem Franom Levstikom (1831-1887), ki se je jasno in brezkompromisno bojevala za Zedinjeno Slovenijo in javno veljavo slovenščine, se v tem času še ni uspela vidneje uveljaviti, saj je vlada njen časopis Naprej leta 1863 zatrla že po nepolnem letu izhajanja (Šumrada 2005).

Habsburški vojaški poraz v boju s Prusijo leta 1866 je ugodno vplival na demokratizacijo političnega življenja in pri Slovencih še pospešil politični ter kulturni razvoj. Dunajski vladajoči krogi so vojaški polom razrešili s političnim sporazumom oziroma nagodbo z madžarskimi elitami in s preureditvijo države v dualistično monarhijo leta 1867, izvedeno na škodo slovanskih narodov. Velika evropska sila pa poslej Avstro-Ogrska monarhija v bistvu ni bila več; vedno bolj se je opirala na mogočno nemško sosedo in od nje postajala vse bolj odvisna.

\section{Matica slovenska - preseganje deželnih meja in njeno kulturno delovanje}

Angleški zgodovinar A. J. P. Taylor je zapisal, da so nekatere narode oziroma njihova preporodna gibanja v Habsburški monarhiji pravzaprav ustvarili ljudje peresa (Grdina 1999). Slovenci smo svoj kulturni boj gradili na podlagi pogledov nemškega filozofa Herderja, ki je jezik razumel kot temelj vsakega naroda, zato je na oltar njegovega oblikovanja postavljal kulturo (Seton-Watson 1980). Herderjevo delo je navdihovalo tudi razvoj ideje slovanskega povezovanja, tako imenovanega panslavizma, in njegove snovalce spodbujalo k utemeljevanju različnosti med slovanskimi narodi in Nemci, s čimer so se postavljale ločnice med njimi. Herder je v svojem znamenitem delu Ideen zur Geschicte der Menschheit iz leta 1784 Slovanom za razliko od Nemcev - pripisal nagnjenje do demokracije, miroljubnosti, glasbe, narodne poezije. Pomembno 
je dejstvo, da gibanje ni bilo usmerjeno proti Monarhiji, vendar je zahtevalo njeno preobrazbo (Čepič 1979; Hroch 1985; Melik 1998; Grdina 1999).

Temeljna zahteva je bila združiti v celoto vsa ozemlja, na katerih smo živeli Slovenci. Jasno je bilo, da je treba preseči deželno razcepljenost in Slovence strniti. Ta boj za konsolidacijo slovenskega ozemlja se je začel najprej v duhovni sferi, zlasti prek delovanja na kulturnem področju. Krmilo kulturnega boja je prevzela leta 1864 ustanovljena Matica slovenska, vseslovensko založniško, znanstveno in kulturno društvo. Beseda 'matica' kot ime za narodno organizacijo, ki skrbi za izdajanje knjig, se je med zahodnimi in južnimi Slovani razširila v 1. polovici 19. stoletja. Na slovenskem ozemlju se je prvič pojavila leta 1845, in sicer $\mathrm{v}$ tedenskem časopisu Kmetijske in rokodelske novice $\mathrm{v}$ članku o prizadevanjih za ustanovitev takega društva. Temeljno vodilo Matice je bilo širjenje literature v slovenskem jeziku, in se s tem zoperstaviti nemščini oziroma germanizaciji, ki je bila bolj ali manj stranski proizvod želje po državnem poenotenju in organiziranja učinkovite državne uprave. V prvih desetletjih delovanja je Matica slovenska kot osrednja kulturna ustanova nadomeščala univerzo ter akademijo znanosti in umetnosti, zato so jo imenovali za "mater našega znanstvenega slovstva" (Melik 1997). Matičin vsenarodni značaj je pomenil, da je vodila drugo obdobje narodnega gibanja, ki je po Hrochu sledilo obdobju "zanimanja učenjakov «, to je obdobje tako imenovane "patriotske agitacije« (Hroch 1985). V tem obdobju se je začel proces oblikovanja narodne zavesti, pri čemer so ideje zanesenjakov dosegle širše množice. Delovanje Matice slovenske ni bilo predstavljeno le v njenih publikacijah in Letopisu, pač pa tudi v slovenskem poljudno-strokovnem tedniku Novice gospodarske, obertnijske in narodske, ki jih je urejal »oče naroda«, Janez Bleiweis. Kot že ime pove, je bil časopis v prvi vrsti namenjen »malemu človeku«, z željo, da bi se dvignil na višjo gospodarsko in kulturno raven, pa tudi izobražencem. Slovenska leposlovna in strokovna besedila je uporaba ljudskega jezika približevala ljudem. Bleiweis je namreč kot edino učinkovito sredstvo narodne osvoboditve videl jezik in kulturo, temelječo na kmečki tradiciji in slovanski složnosti (Slovenski narod 1873).

Matica slovenska se je že na začetku delovanja zavezala, da bo pomanjkanje narodopisnega in domoznanskega čtiva nadoknadila z izdajanjem zgodovinskih in geografskih orisov slovenskih dežel, ki so jih $\mathrm{v}$ tem času začeli pripravljati izobraženi domoljubi in člani Matičinega odbora. Sledila je ideji, da moč in veljavnost naroda izhaja iz knjig v domačem jeziku, s katerimi se narod lahko ponaša. Potreba po geografski literaturi je izhajala iz prepričanja, da je za krepitev narodne zavesti nujno ne le dobro poznavanje lastne dežele, ampak tudi drugih, bolj ali manj oddaljenih tujih dežel. Pomembno je dejstvo, da je bila Matica naddeželna organizacija, ki je pri svojem delovanju stremela k preseganju deželnih meja in zadovoljevanju potreb vseh članov, ne glede na to, v kateri avstrijski deželi živijo.

Matica je svojo založniško dejavnost začela z zemljepisnimi deli, natančneje s kartografijo. Poleg Koledarja slovenskega za leto 1865 so njeni člani najprej prejeli znameniti Kozlerjev Zemljovid Slovenske dežele in pokrajin, ki je bil avtorjevo darilo Matici. Poleg nedvomne znanstvene vrednosti, saj je nastal na osnovi državne statistike in terenskega opazovanja, je neprecenljiva njegova moralna vrednost, saj v novi luči prikazuje strnjeno ozemlje slovenskega naroda. Razumljivo je torej, da je naslednjih sto let služil za izhodišče slovenskih narodnih zahtev (Prunk 2000). Z izdajo zemljevida, ki je jasno odražal težnje po Zedinjeni Sloveniji, je Matica kaj kmalu nakazala svojo primarno vlogo.

Knjige, ki so sledile, so odražale podobne ideje. Njihov glavni namen je bil predstaviti tiste dežele znotraj Habsburške monarhije, v katerih strnjeno živijo Slovenci, ob tem pa pokazati, da te dežele pripadajo Slovencem. S Slovenci poseljeno ozemlje si je prizadevala nazorno umestiti kot samostojno enoto znotraj Monarhije (Granda 2001). Prvi dve geografski publikaciji sta bili Vojvodstvo Koroško v zemljepisnem, statističnem in zgodovinskem spregledu ter Vojvodstvo Kranjsko v zemljepisnem, statističnem in zgodovinskem spregledu. Avtor obeh je bil Josef Erben, profesor na praški univerzi, prevajalec pa Matej Cigale. Sledil je delen opis Štajerske, nato pa je ideja o podrobnem prikazu vseh dežel zamrla. Ponovno so jo oživili leta 1892, vendar tudi zbirka Slovenska zemlja ni bila uresničena v celoti. V nasprotju s prvim poskusom so bili v drugem avtorji večinoma Slovenci. Tudi učbeniki v slovenskem jeziku so bili najprej le prevodi tujih del. Matej Cigale je prevedel in priredil Schubertov zemljepisni učbenik z naslovom Početni nauk o zemljepisu za prvi razred nižjih gimnazijcev in realnih šol, vendar knjiga ni nikoli izšla. Posebna vrednost del, pri katerih je sodeloval Cigale, so bili prirejeni slovenska zemljepisna imena in strokovni izrazi, saj so vsi izobraženci tistega časa, ki so se ukvarjali z zemljevidi ali domoznanstvom, občutili pomanjkanje slovenske geografske terminologije (Bohinec 1925). Izpod peresa slovenskega avtorja so se prvi srednješolski učbeniki za geografijo pojavili v šestdesetih in sedemdesetih letih 19. stoletja. Za izdajo pod okriljem Matice slovenske jih je napisal zaveden Slovenec Janez Jesenko (1838-1908), na dunajski univerzi šolan geograf in zgodovinar. 


\section{Matej Cigale, slovenski izobraženec}

Matej Cigale (1819-1889) je prototip narodno zavednega intelektualca (Vodopivec 1998). Rojen je bil v kmečki družini, vendar je kmalu pokazal veliko nadarjenost, ki ga je popeljala v šole v Idriji, Gorici, Ljubljani, Gradcu in nazadnje na Dunaju. Na liceju v Gorici se je seznanil s klasičnimi, romanskimi in germanskimi jeziki. Pri študiju teologije ter pozneje prava je svoje znanje dopolnjeval in nadgrajeval s slovanskimi jeziki, zlasti hrvaškim, srbskim, ruskim in češkim. V prelomnem letu 1848 je v Celovcu opravil izpit za sodnika, vendar zaradi pomanjkanja finančnih sredstev svoji poklicni želji ni zmogel slediti; sodniški pripravniki namreč niso bili plačani, državna podpora pa je bila zaradi revolucionarnih dogodkov začasno ustavljena.

Na povabilo tiskarja Blaznika je v Ljubljani prevzel urejanje novega časnika Slovenija in postal tajnik Slovenskega društva, katerega temeljni namen je bil gojiti domači jezik in književnost. Že konec leta 1849 ga je usoda ponovno pripeljala na Dunaj, kjer je bil v državni komisiji za juridično-politično terminologijo za slovanske jezike imenovan za slovenskega urednika državnega zakonika. To imenovanje ga je dokončno in za vedno odvrnilo od sodniške službe, saj je do konca življenja skrbel za slovensko pravno izrazje ter prevode vseh zakonov, naredb, ukazov in uradnih razglasov. Celih 38 let je vestno in požrtvovalno »... odbiral, likal in čistil jezik za rabo pravnikom ... « in bil zaradi svojih zaslug imenovan za vladnega svétnika (Majaron 1887 in 1889; Navratil 1894).

Njegovi temeljni vodili, ki sta ga gnali skozi življenje, sta bili slovanska vzajemnost in razvoj slovenskega jezika: »... slovenščino je čistiti in razvijati, a to ne imej namere, povečevati razliko med sedanjimi Slovani, dočim je bližanja želeti ... « (Majaron 1887, 252). Tudi pri delu na področju razvoja geografske vede ga je vodilo domoljubje in delovanje v dobrobit slovenskega naroda, pri čemer je razumel jezik kot temelj narodne zavesti. Cigale spada v skupino narodno zavednih Slovencev, ki svojega statusa in položaja niso dosegli ne na gospodarskem ne na poslovnem področju, ampak jim je do uradniških mest, svobodnih poklicev ali drugih intelektualnih služb pripomogla izobrazba (Vodopivec 1998).

\section{Atlant: prvi atlas sveta v slovenskem jeziku}

Izdaja Atlanta, prvega atlasa sveta v slovenskem jeziku, je bila korak naprej. Prejšnje geografske publikacije so se ukvarjale predvsem z ozemljem, poseljenim s Slovenci, in so želele utrditi zavest »slovenskosti« pokrajin, kjer Slovenci živijo, z atlasom sveta pa je Matica slovenska želela umestiti Slovence in slovenski jezik v širši okvir, na svetovni zemljevid, postaviti slovenski jezik ob bok jezikom večjih narodov in Slovencem povedati, da so enakopraven del celotnega sveta. Danes bi temu lahko rekli prehod iz lokalnega na globalno.

Prvi atlas sveta v slovenskem jeziku je izšel tri stoletja po izidu prve slovenske tiskane knjige Primoža Trubarja Katekizem iz leta 1550 in izidu sploh prvega atlasa sveta Abrahama Orteliusa Prikaz sveta (latinsko: Theatrum orbis terrarum) iz leta 1570.

Atlant je izhajal po listih. Po trije listi so izšli v letih 1869, 1871, 1872, 1874, 1875 in 1877, kar je skupaj 18 zemljevidov. Večina je dolgih med 40 in $42 \mathrm{~cm}$ ter širokih med 30 in $32 \mathrm{~cm}$. Njihovi naslovi so: Obraz cele Zemlje v polutah, Evropa, Avstrija, Nemško cesarstvo, Švica, Italija, Španija in Portugalsko, Francija, Nizozemsko in Belgija, Velika Britanija in Irsko, Skandinavija, Rusija, Turčija in druge vzhodne dežele, Azija, Afrika, Severna Amerika, Južna Amerika ter Avstralija. Zemljepisna imena je pripravil pravnik Matej Cigale (1819-1889). Zanimivo je, da je za Atlantski, Indijski in Tihi ocean uporabil imena Atlantsko morje, Veliko morje in Indijsko morje, za Antarktiko pa Južno-tečajna celina. Za Beljak je napisal Belak, za Trbiž Terbiž, za hrvaški Osijek Osek, za srbski Beograd Belgrad, za nemški München Mnihov, za švicarski Basel Bazileja, za romunsko Bukarešto Bukreš, za turški Istanbul Carjigrad, za Dansko, Norveško in Švedsko Danija, Norvegija in Švedija, za Škotsko Škocija, za Sredozemsko morje Srednje morje, kozorogov povratnik pa je prevedel kot povratnik divjega kozla. Čeprav nekatera zemljepisna imena danes zvenijo nenavadno ali celo smešno, pa je Matej Cigale opravil izjemno delo, saj je številna tuja imena s prevodom ali podomačitvijo prvič zapisal v slovenskem jeziku.

Kljub izjemnemu pomenu je Atlant skoraj povsem utonil v pozabo, na kar kaže tudi dejstvo, da ga v podrobnem pregledu avstrijske kartografije ne omenja niti zajetna publikacija Atlantes Austriaci (Dörflinger in Hühnel 1995). 
Po osamosvojitvi Slovenije leta 1991 je mlada država poskušala utrditi slovensko identiteto, podobno kot Atlant v 19. stoletju, zato je posebno pozornost namenila temeljnim geografskim delom. Izšle so številne obsežne knjige o Slovencih, Sloveniji in slovenskih pokrajinah (Orožen Adamič in sodelavci 1995; Perko in Orožen Adamič 1998; Fridl in sodelavci 1998; Fridl in sodelavci 2001), leta 2005 pa je Geografski inštitut Antona Melika Znanstvenoraziskovalnega centra Slovenske akademije znanosti in umetnosti ponovno izdal Atlant (Fridl in sodelavci 2005). Publikacijo sestavlja 18 zganjenih barvnih faksimilnih zemljevidov in knjiga s spremnimi študijami na 96 straneh. Zemljevidi in knjiga so vloženi v kartonasto šatuljo.

\section{Kartografija kot oblika znanja}

Zemljevidi ne prikazujejo le nekakšnega naravnega stanja v prostoru, temveč izražajo vrsto zgodovinskih, družbenih in političnih dogajanj določenega obdobja. To je še zlasti izrazito, kadar poleg vidnih oblik ponazarjajo človeku nevidne pojave. Kartografska definicija, da so karte odsev sveta v določenem času, velja že vrsto let za pomanjkljivo ali celo neustrezno, saj zajema le tehnične postopke in kartografska znanja, ki se zrcalijo v »vse bolj izpopolnjeni upodobitvi« realnosti (Pickles 1992, 194). Poglobljena sociološka analiza pa zemljevide prikazuje v novi luči, saj jih ne obravnavamo več zgolj kot sredstva za orientacijo, za določanje položaja določenih krajev ter za ugotavljanje dogajanj v določenem časovnem obdobju, ampak imajo mnogo širšo sporočilno vrednost. $Z$ vidika teorije intertekstualnosti so zemljevidi »grafična besedila«, ki so, podobno kot pokrajine, kompozicije skladb ali arhitekturne zgradbe, uvrščena med neknjižna besedila. Metafori zemljevida kot jezika nekateri kartografi sicer nasprotujejo, saj z literarnega vidika grafična besedila ne temeljijo na slovnici in časovnem sosledju stavkov (Harley 1992). Vendar za samo besedilo $\mathrm{v}$ širšem pomenu besede niso konstitutivni jezikovni elementi, temveč dejanje strukturiranja (McKenzie 1986, 35). S tega zornega kota zemljevidi ustrezajo definiciji besedila, saj je znano dejstvo, da so se kartografski simboli kot kod za sporazumevanje razvili celo pred črkovnimi kodi.

Razvoj kartografije so že od Eratostena dalje usmerjali vodilni družbeni sloji, ki so imeli v rokah oblast in moč, saj so se zavedali, da so zemljevidi zaradi svoje vizualne moči zelo uporaben medij kulturnega, ideološkega in nacionalnega prisvajanja stvarnosti (Šaver 2005). Dokaz za to so na primer prizadevanja raznih vladarjev, da so kot izhodiščni poldnevnik ali meridian uporabljali tistega, ki je potekal čez ozemlje njihove države. Na izbiro izhodišča stopinjske mreže zemljevidov Atlanta je vplivala odločitev francoskega kralja Ludvika XIII., ki je leta 1634 določil, da se za začetni poldnevnik uporablja Ferro, najzahodnejši izmed Kanarskih otokov. Enako izhodišče je pozneje prevzela tudi Avstro-Ogrska (Fridl 2005). Vprašanje določitve začetnega poldnevnika se je še posebej zaostrilo na začetku 19. stoletja, ko so kartografske velesile za izhodiščne poldnevnike izbirale tiste, ki so potekali prek njihovih glavnih zvezdarn. Tako so Francozi kot začetni meridian uvedli Pariz, Rusi Pulkov blizu Sankt Peterburga, Italijani Monte Mario v bližini Rima in Angleži Greenwich z zvezdarno v bližini Londona (Slukan Altić 2003). Neusklajenost je opaziti tudi v Atlantu, saj se na nekaterih zemljevidih pojavita kar dva izhodiščna meridiana - Ferro in Pariz. Greenwich so kot svetovni začetni poldnevnik določili šele s konvencijo na mednarodnem geodetskem kongresu v Washingtonu leta 1884, kar kaže na takratno prevlado Britanskega imperija.

Zemljevidi sveta, celin in dežel so začeli dobivati sodobnejšo podobo v 16. stoletju. K temu so največ pripomogli težnje evropskih vladarjev po odkrivanju in osvajanju novih dežel ter prenašanje tehničnih znanj z Daljnega vzhoda v Evropo, še posebej iz Kitajske. Vse to je omogočilo, da so na zemljevidih sveta postopno začele izginjati bele lise, ki so jih od 14. do začetka 19. stoletja prekrivali s podobami mitičnih likov. Točneje izračunane zemljepisne dolžine in širine posameznih krajev na Zemlji so omogočile posodabljanje Ptolemejevih kartografskih projekcij, ki so bile s ponatisi njegovih del v veljavi vse do prve polovice 16. stoletja. Vendar je moralo preteči kar nekaj časa, da so s pomočjo natančnejših topografskih kart posameznih dežel izdelali prvi splošnogeografski zemljevid Evrope, podoben današnjemu. To se je zgodilo na začetku 19. stoletja, v obdobju, ko so se pojavile tudi prve težnje po umestitvi slovenskega naroda na politični zemljevid Evrope (Fridl 1995).

Pri pripravi prvega atlasa sveta smo se Slovenci nedvomno oprli na dela nemških kartografov, o čemer priča tudi videz zemljevidov Atlanta. Za prikazovanje tridimenzionalnega reliefa $\mathrm{v}$ tlorisni perspektivi je bila uporabljena metoda črtic, ki so jo v 18. stoletju iznašli habsburški vojaški kartografi. Leta 1799 je metodo izpopolnil saški kartograf Johann Georg Lehmann, ki je natančno določil razmerje med nagibom terena in gostoto črtic (Perko 2001). Njene pomanjkljivosti se pokažejo zlasti pri prikazovanju visokogorij. Nazorna 
primera sta območje Alp na zemljevidu Nemškega cesarstva in na zemljevidu Švice. Zaradi večjega merila zasedajo črtice na karti Švice skoraj celotno površino, tako da se drugi topografski elementi v njih dobesedno izgubijo.

Z gotovostjo je mogoče trditi, da so bile za posamezne liste Atlanta uporabljene različne kartografske predloge. To na primer dokazuje dejstvo, da so na nekaterih zemljevidih, na primer na listih Evrope, Azije in Avstralije, reke prikazane pretirano vijugasto. Okljuki so enakomerno razporejeni vzdolž celotnega vodotoka, tako da je na prvi pogled jasno, da ni prikazan njihov dejanski tok. Takšen način prikazovanja vodnega omrežja je bil značilen za zemljevide, ki so izšli kakšnih dvesto let pred Atlantom. Navedeno pomanjkljivost so na pozneje izdanih listih odpravili.

Z jasno začrtanimi političnimi in administrativnimi mejami je Atlant pomemben zgodovinski dokument. Med pomembnejšimi imperiji, manjšimi državami in številnimi kolonijami slovenskega ozemlja še ni mogoče zaznati. Prisotnost slovenskih toponimov, ki posredno kažejo na regionalne značilnosti in etnično pripadnost Slovencev nekemu ozemlju, so za dojemanje prostora v izbranem zgodovinskem obdobju tako pomembni, da je tej problematiki namenjeno samostojno poglavje.

Pot uveljavitve slovenskega jezika v širšem evropskem kulturnem prostoru ni bila lahka. Nekatere uveljavljene kartografske hiše namreč niso bile pripravljene tiskati atlasa v slovenskem jeziku, z izgovorom, da bo zadeva predraga ali, da posla ne morejo prevzeti zaradi obilice dela. Matica slovenska je nazadnje sklenila pogodbo s Friedrichom Kökejem, lastnikom geografskega ustava na Dunaju. Atlant je bil tiskan $\mathrm{v}$ za tedanji čas revolucionarni tiskarski tehniki - litografiji, ki se je v kartografiji začela uporabljati komaj pred nekaj desetletji. Z vidika tehničnih postopkov izvedbe so zemljevidi Atlanta tako kot Z vidika njihove intertekstualne vloge primerljivi s svetovnimi atlasi v 19. stoletju jezikovno bolj uveljavljenih narodov.

Ko govorimo o Atlantu, se moramo torej zavedati, da njegov sistem kartografskih simbolov ne deluje le na primarni sporočilni, to je kartografsko-znakovni ravni, temveč ga je treba z vidika teorije intertekstualnosti pojmovati tudi metaforično. To pomeni, da je treba prepoznati tudi njegova sekundarna sporočila, kakor jih je pogojeval zgodovinski in družbeni položaj evropskih narodov v drugi polovici 19. stoletja.

\section{Dojemanje sveta prek zemljepisnih imen}

Zemljepisna imena nam pripovedujejo o naravnogeografskih značilnostih, kulturi, zgodovini in ljudeh določenega območja. Pojavi niso poimenovani le po njihovih naravnih lastnostih, ampak tudi po pomembnih osebnostih, zgodovinskih dogodkih, literarnih predlogah, verskih vzgibih in celo smešnih okoliščinah. Določeno ime v različnih deželah, nam lahko na primer skupaj z njegovimi krajevnimi različicami pojasni razširjenost določenega kulturnega ali zgodovinskega dejavnika, denimo vojaških zavojevanj ali kolonizacije (Kadmon 2000). Pomen zemljepisnih imen za človeško družbo je nazorno definiral Vallières (1992, 46):»... Toponimika, če priznamo ali ne, je del osnovnih znanj vsakega človeka na našem planetu...", saj bi bili brez zemljepisnih imen prikrajšani za enega najpomembnejših prostorskih okvirov našega ožjega in širšega življenjskega okolja na Zemlji. Ali kot dodaja Ó Maolfabhail (1992, 11): »... Naši zemljevidi ostajajo brez povezave s človekom, dokler jih ne obogatijo zemljepisna imena...«.

Tuja zemljepisna imena so se $\mathrm{v}$ slovenščini začela pojavljati v učbenikih iz prve polovici 19. stoletja. Prvi jih je v večjem številu in sistematično predstavil Janez Jesenko, ki je v svojem učbeniku (Jesenko 1865) najprej navedel slovenska imena celin in glavnih svetovnih morij, v nadaljevanju pa je pri posameznih celinah navedel imena glavnih polotokov, rtov in njihovih držav oziroma najbolj znanih pokrajin, medtem ko je pri svetovnih morjih navedel njihova robna morja in večje zalive. Navaja tudi glavne otoke in najznamenitejše prelive. V nadaljevanju po celinah navede glavna jezera in reke, gorovja, pomembnejše vrhove, večja nižavja. Tabelarično so zapisana tudi večja evropska mesta in največja mesta na drugih celinah.

Jesenkov nabor več sto zemljepisnih imen je bil gotovo pomemben zgled za Cigaletovo delo pri pripravi Atlanta, čeprav je nekatere Jesenkove navedbe v časopisnih polemikah, gotovo tudi zaradi medsebojnega rivalstva, ostro kritiziral. Kritičen je bil zlasti do njegovih občih izrazov, medtem ko na zemljepisna imena ni imel večjih pripomb (Kladnik 2005).

Na vseh zemljevidih Atlanta je 28.075 zapisov imen in posameznih občih pojmov, od tega jih je 5907 ali $21 \%$ podomačenih. Različnih zapisov imen je 22.233, 5842 zapisov pa se pojavi dvakrat ali večkrat. Podomačenih je 4651 različnih zemljepisnih imen (Kladnik 2005). Slovenjena so vsa glavna, pomembnejša zemljepisna imena, zato lahko Cigaleta ob Jesenku upravičeno razglasimo za njihovega utemeljitelja. 
Kljub izrednemu pomenu za razvoj slovenskega jezika pa Atlant pozneje ni doživel ustreznega odziva. Še več, Bohinec (1925) je v prvi številki Geografskega vestnika zapisal, da je Cigale videl v Atlantu le filološki problem, pri čemer naj bi bili točna predstavitev krajevnih imen in dodana kratka terminologija njegova edina dobra stran, ki pa za geografijo »ne znači nobenega napredka« (Bohinec 1925, 13), saj je geofizikalna plat popolnoma zanemarjena, prav tako metodični prikaz. Kakšna zmota! Kljub nekaterim pomanjkljivostim se vseh 18 listov kartografsko lahko postavi ob bok Kocenovim in drugim dosežkom iz druge polovice 19. stoletja, vsebina pa je neprecenljiv vir za preučitve in utemeljevanje slovenskega geografskega imenoslovja. Slovenski jezik je torej že skoraj stoletje in pol obogaten s precejšnjim številom podomačenih zemljepisnih imen.

Cigale je imel izjemen čut za uravnoteženo podomačevanje imen iz vseh delov sveta. Težko bi rekli, da ga je k temu opravilu navdihoval določen jezik, očitno pa se je oprl na pomensko zvrst zemljepisnih imen in na pomen določenega imena, ki izhaja iz velikostnega reda določenega pojava. Večje in zgodovinsko pomembnejše pokrajine, gorovja, reke in druge pojave je deloma prevajal deloma transkribiral, tako da je imenoslovje lahko prilagodil slovenskemu črkopisu, deloma pa s fonetičnim zapisom prilagajal slovenski izreki, pri čemer je po potrebi dodajal slovenske končnice. Prevedel je na primer imena Britanska Kolumbija (British Columbia), Skalno gorovje (Rocky Mountains), Tiho morje (Pacific Ocean oziroma Mare Pacifico), Gornje jezero (Lake Superior) in Jakopov zaliv (James Bay), pa tudi nekatera imena, ki jih v sodobnosti redko (na primer Modro gorovje za avstralske Blue Mountains), znova (na primer Nebeško gorovje za Tian Shan, ki smo ga prej po ruskem vzoru domačili v Tjanšan) ali nič več ne podomačujemo (na primer Kraljičina dežela za Queensland ali Novi Jork za New York). Transkribirana so na primer imena Beludžistan (Balūchistān), Jenisej (Enisej), Šan-tung (Shandong) in Okinava (Okinawa Jima), izreki prilagojena pa Estremadura (Extremadura), Kalifornija (California), Sumatra (Sumatera) Tasmanija (Tasmania) in Loara (Loire).

Tako kot na sodobnih zemljevidih je delež podomačenih imen večji na splošnih zemljevidih sveta in celin, manjši pa, z izjemo »domovine« Avstrije, pri prikazih posameznih evropskih držav. Tako je na zemljevidih Obraz cele Zemlje v polutah podomačenih kar 56,5\% imen, na zemljevidih Severne Amerike 45,3\%, Evrope 44,7\% in Azije 43,3\%. Po deležih 35,5\% oziroma 35,3\% sta si zelo podobna zemljevida Avstralije in Avstrije, medtem ko sta Afrika z 22,4 \% in Južna Amerika z 19,8\% nekako na ravni Nemškega cesarstva (26,6 \%), Turčije in drugih vzhodnih držav (22,7\%) ter Rusije (prav tako 22,7\%), bližnjih dežel torej, kjer so (bile) prisotne tudi močne slovanske korenine, kar je bil pomemben vzgib za podomačevanje imen (Kladnik 2005).

Deleži podomačenih imen se precej razlikujejo glede na njihovo pomensko zvrst. V celoti so podomačeno zapisana poimenovanja ljudstev, celin in zgodovinskih pokrajin. Več kot polovica podomačenih imen je tudi pri zapisovanju imen držav $(81,9 \%)$, morskih hidronimov $(79,2 \%)$, obalnih reliefnih oblik $(61,3 \%)$ in upravnih enot $(55,8 \%)$. Stopnja podomačevanja naselbinskih imen je precej nižja; slovenjenih je le $8,7 \%$ imen naselij.

Zapisovanje je $\mathrm{z}$ izjemo prečrkovanj iz cirilskih pisav, kar je $\mathrm{v}$ mnogih primerih vodilo $\mathrm{v}$ podomačevanje, razmeroma daleč od sodobnih prečrkovalnih norm za posamezne jezike, vendar kaže na precejšnje Cigaletovo poznavanje značilnosti določenih jezikov, njihovega naglaševanja in zapisovanja v latinici. To potrjujejo tudi napotki za izgovorjavo črkovnih skupin $\mathrm{v}$ posameznih jezikih, zapisani na robovih nekaterih zemljevidov.

Slovenjenje imen sledi takrat še vedno živemu duhu panslovanstva, zato so povsod, kjer so bila v rabi tudi slovanska imena, le-ta zapisana v Atlantu. Tako najdemo na primer na ozemlju zdajšnje Romunije Kraljevo (Craiova), Belgrad (Alba Iulia) in Oraštje (Oraştie). Morda še boljši primeri so na ozemlju zdajšnje Nemčije. Tam, kjer so bila razširjena lužiškosrbska imena, so ta tudi zapisana. Tako so na primer na Mecklenburškem in Brandenburškem zapisana imena naselij Roztoki (Rostock), Ribnica (Ribnitz-Damgarten), Plava (Plau), Branibor (Brandenburg) in Devin (Magdeburg). Podomačena je tudi glavnina poljskih in ruskih imen, slovenjena pa so tudi številna imena na Balkanskem polotoku, na primer Baker (Bakar), Kladenj (Kladanj), Čaček (Čačak), Kragujevec (Kragujevac) in Belgrad (Beograd).

Cigale se je pri podomačevanju očitno opiral na imenoslovje v čeških atlasih, ki so luč sveta zagledali sredi 19. stoletja, dobri dve desetletji pred Atlantom (Zeměpisný atlas podle nejnowějších pramenůw a pomůcek 1842; Merklas 1846). Na to kažejo imena nekaterih večjih mest na jugu zdajšnje Nemčije, ki so očitno zapisana po češkem zgledu, vendar upoštevaje pravila podomačevanja češčine v slovenski jezik: Mnihov (češko Mnichov za München), Rezno (češko Rezno za Regensburg), Norimberg (češko Norim- 
berk za Nürnberg) in morda še najbolj zanimiv Moguč (češko Mohuč za Mainz, izpeljano iz latinskega imena Moguntium). Podobno je za italijansko jadransko pristaniško mesto Ancono kot prednostna zapisana zdaj povsem neznana različica imena Jakin (češko ime), ni pa, zanimivo, Cigale uporabil češkega zgleda Janov za pristaniško mesto Genovo.

Sicer pa na nemško predlogo Atlanta kaže uporaba nekaterih nemških in angleških imen v oddaljenih deželah, ki jih Cigale bodisi ni hotel bodisi ni znal ali pa jih je pozabil podomačiti. Značilni primeri za to so kraj Peterhof (Petrov Dvorec v Rusiji), mesti Tiflis (Tbilisi v Gruziji) in Oporto (Porto na Portugalskem), otočje Grenadinen (Grenadine v Malih Antilih). Številna zemljepisna imena kažejo na od sodobne precej drugačno politično, narodno in jezikovno podobo druge polovice 19. stoletja. Tako je na primer za zdajšnji Kaliningrad (nekdanji vzhodnopruski Königsberg) uporabljeno slovansko ime Kraljevec, za finska Helsinke in Turku švedski imeni Helsingfors in Åbo, za latvijski Jëkabpils nemško Jakobstadt, za romunska Konstanco ( Constanța) in Beiuş turško Köstendže in madžarsko Belenyes, za hrvaške Nerezine na otoku Braču italijansko Neresi, za južnotirolski Trento nemško Trident, za francoski Strasbourg nemško Strassburg in za belgijski Liège nemško ime Lütich (Kladnik 2005).

Zaznaven je razkorak v razdelanosti imenoslovja med takrat že dobro poznanimi deželami in tistimi, ki so jih evropski raziskovalci šele začenjali »odkrivati«. Tako so na primer v osrčju Afrike še obsežne bele lise, na njihovem obrobju pa so nekatera imena »eksotična«; zdaj o mnogih ni več sledu. Podobno je tudi ponekod v Oceaniji.

Čeprav nekatera takratna zemljepisna imena v sodobnosti zvenijo nenavadno ali celo smešno, je Cigale opravil izjemno delo, saj je številna tuja imena s prevodi in podomačitvijo prvič sistematično predstavil v slovenskem jeziku. Nikakor ni mogoče spregledati njegovega kritičnega pristopa, saj je v Atlantu nakazal nekatere izredno dobre rešitve, ki so bile pozneje zlasti pod vplivom rusifikacije in srbohrvaščine izmaličene. Tako je na primer za nekatere pokrajine na Antarktiki in Arktiki, pa tudi na območju Avstralije uporabil slovenski občeimenski izraz dežela (na primer Wilkezova dežela na Antarktiki, Washingtonova dežela na Grenlandiji, Van Diemenova dežela ali Tasmanija v Avstraliji), ki smo ga na naših zemljevidih do pred kratkim po srbohrvaškem vzoru zapisovali kot zemlja.

\section{Atlant kot ogledalo predstav o sebi in drugih}

V drugi polovici 19. stoletja si je slovenščina počasi in s težavami utirala pot iz vsakdanjega jezika neizobraženih ljudi v uradniški, sodni in učni jezik, s tem pa tudi v jezik, ki je omogočal znanstveno ustvarjanje. To je bilo obdobje, zlasti po obnovi ustavnosti, ko je jezik močno napredoval. Ustavno življenje je že samo po sebi krepilo in razvijalo bogastvo knjižnega jezika in njegovo izrazno moč (Čepič 1979). Izpopolnjevala se je terminologija, pri čemer ima Matej Cigale izjemno vlogo, saj je postavil temelje slovenskemu znanstvenemu jeziku. Za Slovence je bilo to zelo pomembno, in sicer zaradi pozitivne samopodobe in njihove podobe navzven. Jezik, ki je dolgo veljal za jezik kmetov, je v tem času prvič omogočil znanstveno in najzahtevnejše kulturno ustvarjanje.

Atlant je kot literarno in znanstveno delo ter kot zgodovinski dokument odsev časa in prostora, v katerem je nastajal. Že sam potek organizacijskih aktivnosti v luči prostorskih odnosov kaže na položaj Slovencev pri iskanju lastnega prostora znotraj večnacionalne monarhije ter na odnos med Slovenci in drugimi narodi v njej. Pri iskanju ustrezne kartografske predloge oziroma ustanove, ki bi prevzela izvedbo tako zahtevnega dela, so se najprej obrnili na dve nemški založbi in eno češko. Izbor nemških založb kaže, da so le dobro leto po razpadu Nemške zveze in izločitvi Avstrije iz nje, kar so Slovenci sprejeli z velikim veseljem, vodilni pri Matici presegli avstrijsko-nemška nasprotja (Melik 1993). Zaradi neusklajenih interesov glede tiska Atlanta s strani naprošenih založb je do njegove izvedbe nazadnje prišlo na Dunaju, v prestolnici, kjer je tako kot mnogi slovenski izobraženci - deloval Cigale. Tako je Atlant plod avstrijske tehnologije in kartografskega znanja ter slovenske jezikovne nadgradnje, saj je vlogo njegovega prevajalca, redaktorja in urednika prevzel Slovenec.

Pomen Atlanta in ostale znanstvene literature je bil v tem, da je spodkopaval argumente vladnih predstavnikov, ki so trdili, da pomanjkanje ustreznih izrazov in neizoblikovanost jezika ovirata uvajanje slovenščine v urade. Bil je protiargument nemški in italijanski politiki, ki sta prek kulture branila svoj položaj kolonizatorja (Moritsch 1997). Atlant je dokazal, da je tudi zapostavljen narod sposoben ustvariti pomembna kulturna dela in da slovenščina kot jezik to omogoča. Tako Slovencem kot drugim je pokazal, da je 
slovenščina živ jezik, ki se ga da razvijati. Opozoril je, da so Slovenci narodna skupnost, ki je odločno stopila na pot oblikovanja lastne identitete. Dela Matice Slovenske so pokazala, da Slovenci narodne emancipacije ne nameravajo izsiliti le s političnim bojem, ampak tudi spontano, prek krepitve kulturne in jezikovne zavesti. Prav z Atlantom smo se Slovenci postavili ob bok kulturno in jezikovno razvitejšim narodom, saj $\mathrm{v}$ tistem času tudi nekateri bistveno večji narodi tako obsežnega kartografskega dela še niso imeli.

Znanstvena literatura kaže na to, da so se politično in kulturno ozaveščeni ljudje zavedali, kako pomembna je široka podpora množic za utrditev slovenščine. Prav s knjigami, napisanimi v narodnem jeziku, je znanje in vedenje doseglo tudi preprostega, malega človeka, ki morda ni znal nemškega jezika, bil pa je že pismen, saj je obvezno šolstvo imelo že kar dolgo tradicijo. Tako se je narodna zavest dotaknila širokih množic, ki so prej gojile zgolj lokalno in regionalno pripadnost. Znanstvena literatura je dosegla ne le izobraženstvo, pač pa tudi narodno zavedne množice. O razširjenosti Atlanta govori naklada. Prvi trije kompleti so izšli v nakladi 2000 izvodov, drugi trije pa v nakladi 3000 izvodov. Za primerjavo naj povemo, da je faksimile Atlanta 130 let pozneje izšel v nakladi 1000 izvodov. Torej je bila naklada originala za tisti čas zavidanja vredna, saj znanstvene knjige celo danes izhajajo v manjših nakladah. To nam daje jasno sliko, da Atlant ni bil le znanstvena literatura, pač pa mnogo več. Imel je narodno buditeljsko in pomembno izobraževalno vlogo. Člani Matice Slovenske niso bili le iz najbolj slovenske dežele Kranjske, ampak tudi iz Štajerske, Koroške in Primorske, pa tudi od drugod. Teritorialno torej Atlant in ostale publikacije niso ostali samo v jedru narodne skupnosti, temveč so dosegli mnogo bolj oddaljene kraje.

Atlant je ljudem približal svet in obenem svetu približal Slovence. S svojo intelektualno držo je brisal meje med »mi« in »oni« in Slovence enačil - vsaj na kulturnem področju - z razvitimi evropskimi narodi. Za majhne narodne skupnosti je bil prav jezik tisti ključni dejavnik, ki jih je jasno ločil od drugih in je zato pomagal upravičiti in uzakoniti njihov obstoj. Hroch je tak potek narodne emancipacije imenoval jezikovno-kulturni program, ki so ga vodili in usmerjali domoljubni izobraženci (Hroch 1998). Založniška dejavnost, ki jo je v veliki meri organizirala Matica slovenska, je v nekaj desetletjih dvignila slovenski jezik v jezik, uporaben na vseh ravneh izobraževanja.

Atlant in ostale publikacije so pripomogle h konsolidaciji jezika navznoter in navzven. Zaradi zgodovinske razdeljenosti na dežele je bil tudi jezik pokrajinsko opredeljen, tako kot ljudje, ki so ga govorili. Glavnina izobražencev je bila kmečkega izvora (Vodopivec 1998), kar je bilo med drugim povezano z izboljšano možnostjo zaposlovanja $\mathrm{v}$ uradniških službah tudi za ljudi neplemskega izvora in člane nenemških jezikovnih skupnosti. Prispevek Cigaleta k standardizaciji jezika kot uradnega in knjižnega je pomenil preseganje pokrajinskih partikularizmov. Izobraženci iz različnih pokrajin so sicer govorili različna narečja, vendar so se še posebej zavedali pomembnosti »mobilizacije« širših množic in dejstva, da bo lažje sprejeti skupni splošnoslovenski jezik, neke vrste »lingua franca «, kot pa prevzeti eno od pokrajinskih različic in ji dati vsenarodni značaj.

Atlant in ostala književnost so utrdili položaj jezika tudi navzven in tako postavili Slovence na kulturni in jezikovni zemljevid druge polovice 19. stoletja. Atlant je dvigoval zavest o »mi« in jasno opredelil ločnice do »oni«. Tukaj ne gre le za ločevalno vzpostavljanje odnosov do germanskega prostora, pač pa tudi za iskanje lastnega prostora znotraj slovanske realnosti. Res je, da so bili mnogi izobraženci tistega časa zelo naklonjeni ideji panslavizma in se je konstrukt južnih Slovanov vse močneje in jasneje izražal. A prav z Atlantom in mnogimi drugimi publikacijami se je jasno izkristalizirala edinstvenost in svojskost slovenskega jezika. Dokaz za to trditev je, da je bila kljub težavam, ki so se porajale ob pripravi prvega atlasa sveta v slovenskem jeziku, ob ponujeni možnosti, ki bi vsaj v finančnem smislu olajšala delo, zavrnjena ideja o skupnem hrvaško-slovenskem atlasu. Kljub veliki navezanosti na južnoslovanske narode in na Čehe, so še zlasti slednjim, ki so mislili: »... da smo namreč skorej gotovo za vse večne čase brez vsakega rešenja germanizatorskemu aligatorju v žrelo padli ...« (Čepič 1979, 478), hoteli dokazati edinstvenost slovenskega jezika. To dokazuje tudi Cigaletova misel v Znanstveni terminologiji, da »... smo z Atlantom vendar nekako pretekli druge avstrijske Slovane...«(Cigale 1880, 4).

\section{Sklep}

Z revolucionarnim letom 1848 se je začelo novo poglavje slovenske zgodovine. Ideje Zedinjene Slovenije in z njimi povezane zahteve po rabi narodnega jezika so razburkale in poživile dogajanje na kulturnem in političnem področju. Novi časopisi v slovenskem jeziku in novonastala društva so budila in krepila 
narodno zavest, pri čemer je imela nenadomestljivo vlogo leta 1864 ustanovljena Matica slovenska. Temeljni namen njenega delovanja je bilo splošno izobraževanje Slovencev, kar je uresničevala s podpiranjem slovenskega slovstva ter izdajanjem znanstvenih in poljudnih del. Matica slovenska je svoje poslanstvo začela prav z geografijo oziroma s kartografijo. Med njenimi prvimi dosežki je tudi Atlant, prvi atlas sveta v slovenskem jeziku.

Kljub izrednemu pomenu za spodbujanje narodne zavesti in razvijanje maternega jezika pa Atlant v geografski srenji ni doživel ustreznega odziva, sčasoma pa je skoraj povsem utonil v pozabo. Studije, ki so nastale ob pripravi faksimila Atlanta, so pokazale, da je kljub nekaterim utemeljenim, predvsem jezikovnim kritikam iz časa izhajanja atlasa, neprecenljiv vir za preučevanje in utemeljevanje slovenskega zemljepisnega imenoslovja. Številna zemljepisna imena $v$ atlasu so bila prvič prevedena ali podomačena $\mathrm{v}$ slovenski jezik. V značilnostih njihovega prirejanja se kažejo geografske, jezikovne in politične razmere, v kakršnih smo živeli Slovenci, pa tudi takratna razmerja med slovenščino, nemščino in slovanskimi jeziki, ki so odločala o stopnji podomačitve zemljepisnih imen v slovenščini in o izboru jezika, ki je bil osnova za prevod oziroma podomačitev v slovenski jezik.

Atlant je torej že pred stoletjem in pol obogatil slovenski jezik s precejšnjim številom podomačenih in prevedenih zemljepisnih imen, od katerih so se mnoga ohranila tudi v sodobnem slovenskem jeziku, kar je v obdobju globalizacije, ko se pojavljajo težnje po popolni prevladi angleščine, pomembna vrednota.

Geografija je torej za Slovenijo kot majhno državo izjemno pomembna, saj želi z njeno pomočjo postati čim bolj prepoznavna na sodobnem svetovnem zemljevidu, za Slovence pa je bila pomembna tudi prek celotne narodove zgodovine, saj je prispevala k vzpostavljanju in ohranjanju slovenske narodne zavesti predvsem z izdajanjem podobnih publikacij, kot je Atlant.

Na tak način slovenska geografija prispeva tudi k ohranjanju raznolikosti, kar je ena od najpomembnejših vrednot Evropske zveze.

\section{Viri in literatura}

Glej angleški del prispevka. 